American Journal of Immunology 3 (2): 56-73, 2007

ISSN 1553-619X

(C) 2007 Science Publications

\title{
Microarray Analysis of Human Vascular Smooth Muscle Cell Responses to Bacterial Lipopolysaccharide
}

\author{
${ }^{1}$ Joe Minta, James ${ }^{1,2} \mathrm{~J}$. Yun, ${ }^{1}$ Sandy Der and ${ }^{1}$ Shikha Rana \\ ${ }^{1}$ Department of Laboratory Medicine and Pathobiology, Faculty of Medicine \\ ${ }^{2}$ Applied Molecular Oncology, Ontario Cancer Institute/University Health Network, \\ Toronto, Ontario, Canada
}

\begin{abstract}
Accumulating evidence suggest a causal role of bacterial and viral infections in atherogenesis. Bacterial lipopolysaccharide (LPS) has been shown to stimulate resting vascular smooth muscle cells (SMC) with the production of inflammatory cytokines and modulation of quiescent cells to the proliferative and synthetic phenotype. To comprehensively identify biologically important genes associated with LPS-induced SMC phenotype modulation, we compared the transcriptomes of quiescent human coronary artery SMC and cells treated with LPS for 4 and $22 \mathrm{~h}$. The SMCs responded robustly to LPS treatment by the differential regulation of several genes involved in chromatin remodeling, transcription regulation, translation, signal transduction, metabolism, host defense, cell proliferation, apoptosis, matrix formation, adhesion and motility and suggest that the induction of clusters of genes involved in cell proliferation, migration and ECM production may be the main force that drives the LPS-induced phenotypic modulation of SMC rather than the differential expression of a single gene or a few genes. An interesting observation was the early and dramatic induction of four tightly clustered interferon-induced genes with tetratricopeptide repeats (IFIT1, 2, 4, 5). siRNA knock-down of IFIT1 in SMC was found to be associated with a remarkable up-regulation of TP53, CDKN1A and FOS, suggesting that IFIT1 may play a role in cell proliferation. Our data provide a comprehensive list of genes involved in LPS biology and underscore the important role of LPS in SMC activation and phenotype modulation which is a pivotal event in the onset of atherogenesis.
\end{abstract}

Key words: Vascular smooth muscle cells, lipopolysaccharide, transcriptome, microarray, quantitative PCR, siRNA, IFIT1

\section{INTRODUCTION}

Atherosclerosis is a complex, chronic inflammatory disease of the arterial vessel wall manifested at predilected locations of the vasculature ${ }^{[1]}$. It is initiated by multiple local and systemic risk factors (including mechanical shear stress due to hemodynamic changes, hypercholesterolemia, hypertension, high plasma levels of inflammatory markers, etc.) which induce endothelial dysfunction and vascular injury ${ }^{[1]}$. The disease is characterized by complex interactions between a variety of lipids, mononuclear phagocytes and their soluble mediators in the intima and by intimal hyperplasia. The accumulation of excess cholesterol and cholesteryl esters by macrophages at these sites results in the formation of foam cells that are the hallmarks of early fatty streak lesions and atheroma development ${ }^{[1,2]}$.
Accumulating evidence suggests that chronic viral or bacterial infections, particularly infections with the ubiquitous gram-negative respiratory pathogen, Chlamydia pneumoniae, may be an additional risk factor that may initiate and/or promote atherosclerosis. Patients with acute myocardial infarction and coronary artery disease have been reported to have significantly higher titers of antibodies against $C$. pneumoniae compared to healthy controls and $C$. pneumoniae has been localized to the intima of vascular smooth muscle cells (SMCs) in many atherosclerotic lesions ${ }^{[3,4]}$. C. pneumoniae has been shown to infect and multiply within macrophages, endothelial cells and $\mathrm{SMCs}^{[3]}$ and C. pneumoniae and Chlamydial lipopolysaccharide (LPS) have been reported to induce the release of inflammatory cytokines from mononuclear cells, endothelial cells and $\mathrm{SMCs}^{[5,6]}$ and to stimulate

Corresponding Author: Joe Minta, Department of Laboratory Medicine and Pathobiology, 1 King's College Circle, Medical Sciences Building Room 6211, Faculty of Medicine, University of Toronto, Toronto, ON Canada M5S1A8, Tel: 416-946-0316 
oxidation of low-density lipoprotein and formation of macrophage foam cells ${ }^{[7,8]}$. Failure of coronary artery bridge grafts or restenosis has been associated with chronic inflammation induced by $\operatorname{LPS}^{[9,10]}$. Systemic inflammatory responses induced by LPS have been shown to increase neointimal formation after ballon injury and stent implantation and the induced proliferation of SMCs may play a key role in atherogenesis $^{[11]}$.

LPS is a complex glycolipid component of the gram-negative bacterial cell wall composed of a hydrophilic polysaccharide and a hydrophobic Lipid A moiety ${ }^{[12]}$. The interaction of serum LPS-binding protein (LBP) with LPS facilitates the binding of the lipid A moiety to CD14, a $55 \mathrm{kDa}$ glycoprotein present as a soluble factor (sCD14) or as a glycosylphosphatidylinositol (GPI)-anchored membrane protein $^{[13,14,15]}$. This complex, which also contains MD2, interacts with Toll-like receptor 4 (TLR4) which mediates the cellular activation by LPS. TLR4 signaling induces the activation of NFkB and MAPK pathways and proliferation of $\mathrm{SMCs}^{[16,17,18,19,20,21]}$. Recently, Engelmann et al..$^{[22,23]}$ have reported that repeated perivascular administration of LPS or inoculation of Chlamydophila pneumoniae into rabbits induce formation of atheromatous lesions in vivo.

The ability of VSMCs in the media of arteries to undergo phenotype modulation from the quiescent and contractile state to the proliferative, migratory and synthetic phenotype that elaborates extracellular matrix underlies their crucial role in the development and progression of vascular pathology such as atherosclerosis and restenosis. Phenotype modulation involves a cascade of events in which different genes are turned on or off in a regulated manner. Thus to gain further insight into the molecular events associated with LPS-mediated activation of SMCs, we have analyzed the transcriptomes of quiescent and LPS-treated human coronary artery SMCs using oligonucleotide microarray analysis. Our results show that the transcriptional effects of LPS on SMCs were particularly far-reaching and many genes that are involved in various biological mechanisms such as chromatin remodeling, transcriptional regulation, translation, signal transduction, metabolism, innate and adaptive immune responses, cell proliferation, apoptosis, matrix formation, cell adhesion and motility, were regulated in a coordinated fashion. The LPS effect appeared to be mediated via the transcriptional induction of proinflammatory cytokines and growth factors and these in turn initiated multiple signal transduction pathways that induced transcriptional activation of genes that are effectors of cell proliferation, migration and extracellular matrix formation. The data presented is thus in agreement with accumulating evidence that LPS may be a risk factor that initiates and/or promotes atherosclerosis.

\section{MATERIALS AND METHODS}

Smooth muscle cell culture and reagents: Human coronary artery SMCs (Clonetics, Walkersville, MD) were cultured in SMC basal medium (SmBM) containing SmBM-3 growth supplements [FBS (5\%), bovine insulin $\left(50 \mathrm{ng} \mathrm{mL}^{-1}\right)$, human recombinant (hr)EGF (5.0 ng mL $\left.{ }^{-1}\right)$, hr-FGF-B $\left(20 \mathrm{ng} \mathrm{mL}^{-1}\right)$ and GA1000 (Gentamicin, Amphotericin B)] supplied by BioWhittaker Inc. Walkersville, MD. SMCs were characterized by their typical hill and valley growth pattern, by staining with anti-SM- $\alpha$-actin antibody (Dako Diagnostics) and by the lack of staining of Factor VIII related antigen, an endothelial cell marker, using anti-factor VIII antibody (Dako Diagnostics). SMCs at passage 4 were seeded in growth supplemented SmBM3 medium for $24 \mathrm{~h}$ and the medium was replaced with basal mediun containing $0.5 \%$ FBS for $48 \mathrm{~h}$ to induce quiescence before treated with LPS (E. coli 055.B5, Sigma/Aldrich, St. Louis, MO). Human AB serum was purchased from Sigma/Aldrich, St. Louis, MO. For siRNA experiments, human aorta SMCs (ATCC, Manassas, VA) were cultured in growth supplemented F12K medium according to the instructions of the supplier.

RNA isolation and gene expression profiling: Total RNA was extracted from cells using TRIzol reagent (Invitrogen Life Technologies, Inc. Burlington, ON) and contaminating chromosomal DNA was removed using Rnasefree DNase Message Clean Kit (GenHunter Corp., Nashville, TN). The integrity of RNA preparations was assured by comparing the intensities of $28 \mathrm{~S}$ and $18 \mathrm{~S}$ rRNA bands on $1 \%$ formamidealdehyde agarose gel. mRNA was isolated from the total RNA using Oligotex according to the manufacturer's instructions (Qiagen Inc., Mississauga, ON). Biotinylated complementary RNA (cRNA) samples for chip hybridization were prepared according to protocols supplied by Affymetrix (Affymetrix, Santa Clara, CA) and then hybridized to HG-U133A oligonucleotide array Gene Chip (Affymetrix, Santa Clara, CA) following the manufacturer's protocol. The arrays were washed, stained with streptavidin-phycoerythrin and scanned. Data files were analyzed using Affymetrix GeneChip ${ }^{\circledR}$ Operating Software (GCOS) version 1.0 (Affymetrix, Santa Clara, CA). 
Gene cluster analysis: Gene expression pattern analysis was performed using GENESIS ver. 1.3.0. Raw expression values of differentially regulated genes (above signal log ratio of 1.0) from microarray analysis were adjusted with $\log 2$ transform data and 'median centre genes, and clustered I nto 40 groups using $\mathrm{k}$-mean clustering according to the method of Eisen et al. ${ }^{[24]}$ Groups with similar gene expression pattern were combined together to generate three gene expression patterns: up-regulated at both 4 and $22 \mathrm{~h}$, upregulated only at $4 \mathrm{~h}$ and down-regulated only at $4 \mathrm{~h}$.

Quantitative real-time PCR: Quantitative real-time PCR was performed with an ABI Prism 7900HT Sequence Analyzer using the manufacturer's recommended protocol (Perkin-Elmer Applied Biosystems, Foster City, CA) to validate differential expression of selected genes. Two different primer sets were designed for each investigated gene using Primer Express version 2.0 (Perkin-Elmer Applied Biosystems, Foster City, CA). Each reactions was run in triplicates in $10 \mu \mathrm{L}$ volumes containing $4 \mu \mathrm{L}$ of diluted first strand cDNA template, $5 \mu \mathrm{L}$ of SYBR Green PCR Master Mix, $0.1 \mu \mathrm{L}(50 \mu \mathrm{M})$ of each forward and reverse primers and $0.8 \mu \mathrm{L} \mathrm{H}_{2} \mathrm{O}$. Samples were incubated at 95 ${ }^{\circ} \mathrm{C}$ for $3 \mathrm{~min}$ to activate Taq polymerase and 40 cycles were performed at $95{ }^{\circ} \mathrm{C}$ for $10 \mathrm{sec}$, at $65{ }^{\circ} \mathrm{C}$ for $15 \mathrm{sec}$ and at $70 \mathrm{oC}$ for $20 \mathrm{sec}$. A standard curve of each primer set was generated using human tonsil genomic $\mathrm{DNA}^{[25]}$. Sequences for the primers used in this study are available on request.

siRNA preparation and transfection: Cell cultures at 60-80\% confluence were transfected with custom designed and synthesized IFIT1-specific siRNA primers (Sense: GGC UGU CCG UUU AAA UCC A; Antisense: UGG AUU UAA GCG GAC AGC C) using RNAi Human/Mouse Control Kit and instructions supplied by Qiagen. siRNA ( $30 \mu \mathrm{L}$ of $20 \mu \mathrm{M}$ solution), RNAiFect $(22.5 \mu \mathrm{L})$ and buffer EC-R buffer $(70 \mu \mathrm{L})$ were mixed together and incubated for $15 \mathrm{~min}$ at room temperature to allow formation of tranfection complexes. The complexes were then added drop-wise onto the cells in the fresh medium. A scrambled nonsilencing siRNA that has no known homology with mammalian genes was used to control for non-specific silencing effects.

RT-PCR: RT-PCR was performed using the Superscript first strand synthesis system (Invitrogen), Hotstart Taq Master Mix Kit (Qiagen) and gene specific primers designed from published cDNA sequences.

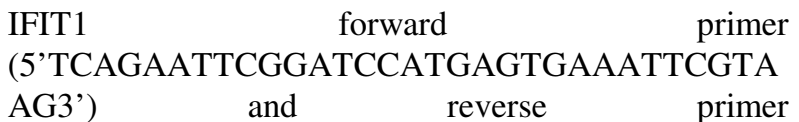
$\begin{array}{llr}\text { AG3') and reverse primer } & \\ \text { (5'CAAGCTTGCCTGCAGTTAAATGGAAAGTCGC }\end{array}$ AG 3') amplifies a $1.5 \mathrm{~kb}$ cDNA fragment. GAPDH forward primer (5'CCACCCAGAAGACTGTGGAT3') and reverse primer (5'CCCCTCTTCAAGGGGTCTAC3') amplifies a 600 bp cDNA fragment. PCR amplification was initiated with a hot start at $95^{\circ} \mathrm{C}$ for $15 \mathrm{~min}$ followed by 35 cycles of denaturation at $94^{\circ} \mathrm{C}$ for $3 \mathrm{~min}$, annealing at $56{ }^{\circ} \mathrm{C}$ for $1 \mathrm{~min}$ and extension at $72^{\circ} \mathrm{C}$ for $3 \mathrm{~min}$ and ended with an extension phase at $72{ }^{\circ} \mathrm{C}$ for $10 \mathrm{~min}$. PCR products were collected and analyzed by electrophoresis on $1 \%$ agarose gel to determine the levels of IFIT1 and GAPDH.

\section{RESULTS AND DISCUSSION}

Effect of LPS on the proliferation of SMC: In order to access the effect of LPS on SMC proliferation, quiescent SMCs in microtiter plates were stimulated with LPS $\left(100 \mathrm{ng} \mathrm{mL}^{-1}\right)$ in the presence of $0.5 \%$ FBS or $5 \% \mathrm{AB}$ serum as source of $\mathrm{sCD} 14^{[26]}$. The culture media were replaced at day 2 and the cells were detached at day 5 and counted. The mean and standard error of the mean were determined for three experiments, each performed in quadruplicates. LPS stimulated SMC proliferation as determined by the increase in cell number over a 5 day culture period Fig. 1. The increase in cell number in cultures containing $0.5 \%$ FBS or $5 \% \mathrm{AB}$ serum, were comparable. In the presence of $0.5 \% \mathrm{FBS}$ and $100 \mathrm{ng} \mathrm{mL} \mathrm{m}^{-1} \mathrm{LPS}$, SMC proliferation was increased 2.4 fold relative to cells in basal medium containing $0.5 \%$ FBS alone and SMC proliferation in medium containing $5 \% \mathrm{AB}$ serum and $100 \mathrm{ng} \mathrm{mL}^{-1} \mathrm{LPS}$ was 5.1 fold greater than in the presence of $\mathrm{AB}$ serum alone. Our results on the mitogenic effect of LPS on SMCs is in agreement with earlier reports ${ }^{[27,28]}$.

Microarray analysis of differential gene expression in LPS-treated SMCs: Confluent SMCs cultures were synchronized to quiescence by incubation for $48 \mathrm{~h}$ in SmBM+0.5\% FBS. To obtain a global profile of the transcriptional changes induced by LPS, we examined the gene expression responses of human coronary artery SMCs stimulated with $5 \% \mathrm{AB}$ serum alone or $\mathrm{AB}$ serum containing LPS $\left(100 \mathrm{ng} \mathrm{mL}^{-1}\right)$ for 4 and $22 \mathrm{~h}$ using Affymetrix oligonucleotide arrays (HGU133A). Of the 18,400 transcripts (14,500 wellcharacterized genes) present on the chips, 1015 


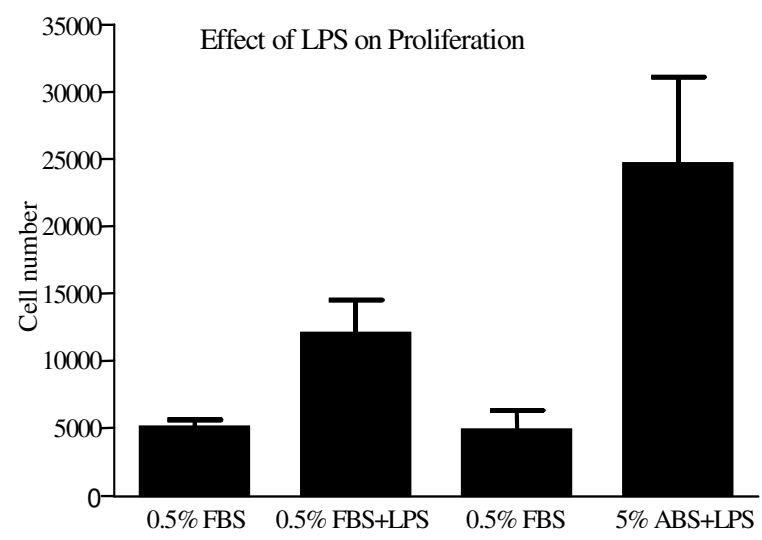

Fig. 1: Effect of LPS on SMC proliferation. $5 \times 10^{4}$ VSMC were seeded in multi-well culture plates and incubated and incubated for $24 \mathrm{~h}$ in basal medium containing $0.5 \%$ FBS to induce quiescence. The cultures were then grown in four different culture conditions $(0.5 \% \mathrm{FBS}$, $0.5 \% \mathrm{FBS}+100 \mathrm{ng} \mathrm{mL}^{-1} \mathrm{LPS}, 5 \% \mathrm{AB}$ serum and $5 \% \mathrm{AB}$ serum $+100 \mathrm{ng} \mathrm{mL} \mathrm{m}^{-1} \mathrm{LPS}$ ) for 5 days and the cell numbers were measured. The mean and standard error of the mean were determined for three experiments, each performed in quadruplicates

and 3749 genes (including ests and redundant gene probes) were found to be differentially regulated by LPS at 4 and $22 \mathrm{~h}$, respectively. 469 genes were induced and 546 were suppressed at $4 \mathrm{~h}$ and 2526 were induced and 1223 were suppressed at $22 \mathrm{~h}$.

Quantitative real-time pcr validation of results of gene array analysis: To validate the gene array results, the expression of 13 regulated genes was analyzed using reverse transcription followed by quantitative real-time PCR. The expression levels of human GAPDH and beta-2-microglobulin were used as internal housekeeping gene controls to normalize technical variability between samples. The expression of 9 genes was shown to correlate well in microarray and real-time PCR whereas the magnitudes of differential expression were somewhat different for 4 genes (data now shown). Overall, the real-time PCR data was more sensitive than the microarray data.

Scatter plot analysis: Scatter plots of log-transformed expression values from microarray analysis for pairwise comparisons of $\mathrm{AB}$ serum+LPS treated SMCs (ordinate) versus the control cells treated with $\mathrm{AB}$ serum alone (abscissa) for 4 and $22 \mathrm{~h}$ were used to display the regulated genes (Fig. 2). The data points along the diagonal represent genes expressed at comparable levels in both sets whereas those that lie off the diagonal represent genes differentially expressed between the samples identified by the two axes. The data indicate that the number of regulated genes increased with time. Also, whereas the number of induced and repressed genes at $4 \mathrm{~h}$ was comparable, the number of induced genes at $22 \mathrm{~h}$ was much greater than that of the suppressed genes. The plots confirmed that LPS induced and suppressed a greater numbers of genes at $22 \mathrm{~h}$ compared to $4 \mathrm{~h}$ (Fig. 2A and B). Scatter plot analysis of SMC treated with $A B$ serum for 4 and $22 \mathrm{~h}$ shows that $A B$ serum induces regulation of genes (Fig. 2C). This effect was more pronounced at $4 \mathrm{~h}$ and appeared to subside by $22 \mathrm{~h}$. Comparison of the scatter plots of SMC treated with AB+LPS for 4 and $22 \mathrm{~h}$ showed that the magnitude of expression appeared to be similar for most genes. This suggests that the robust induction of genes in LPS $22 \mathrm{~h}$ compared to AB $22 \mathrm{~h}$ may be due to the prolonged and sustained activation of genes by LPS which compensates for the diminished $\mathrm{AB}$ serum effect at $22 \mathrm{~h}$ (Fig. 2D).

Profile of down-regulated genes: Since it is possible that the SMC genes that were down-regulated by LPS may be implicated in the maintenance of the quiescent phenotype, we have displayed in Tables 1A and 1B the induction and functional profiles of the top $10 \mathrm{SMC}$ genes down-regulated by LPS treatment at 4 and $22 \mathrm{~h}$. Two transcripts with the greatest fold decrease in expression in $4 \mathrm{~h}$ were albumin and cannabinoid receptor 1 (CNR1). Albumin is the serum carrier protein that plays an important role in stabilizing extracellular fluid volume and is known to be downregulated during acute inflammation. CNR1 is a Gcoupled receptor in brain and some peripheral tissues that recognize plant derived cannabinoids (marijuana) as well as endogenous lipid-like mediators (such as arachidonyl ethanolamide [anandamide] and 2arachidonyl glycerol) that are potent modulators of neurobehavioral functions ${ }^{[29]}$. CNR1 and its endogenous ligands have role in regulating cerebral arterial tone and reactivity by modulating influx of calcium through Ltype calcium channels. Todate, the role of CNRs in SMC phenotype modulation is unknown. Among the down-regulated genes were two prostanoid receptors, PTGDR and PTGER4, a transcription-related gene (HCAP-G), two structural-related genes (D2LIC, PPFIA3), a chloride transporter (CLCN3) and negative regulators of cell proliferation and apoptosis $\left(\mathrm{GW} 112^{[30]}, \mathrm{INHBE}^{[31]}\right)$. 


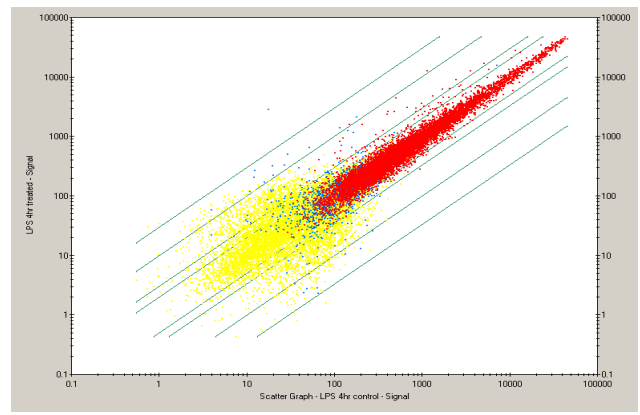

a

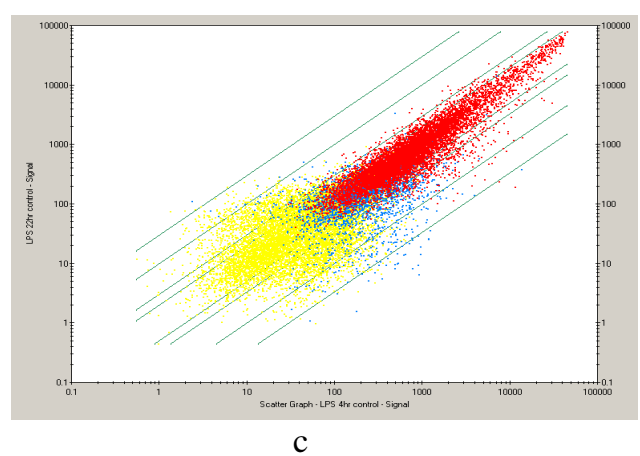

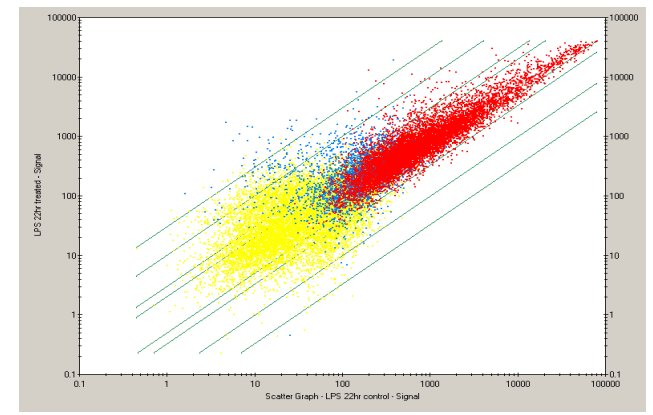

b

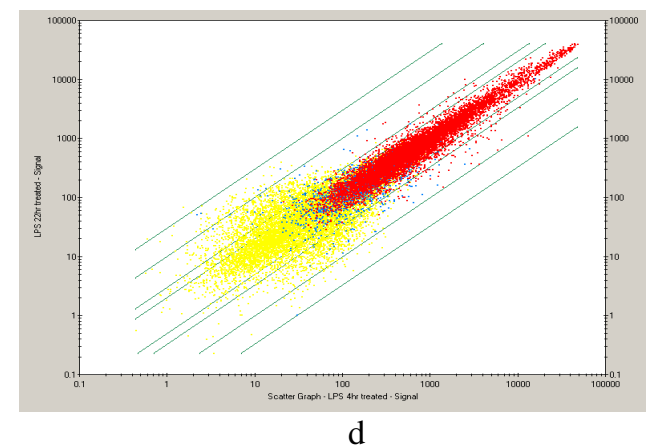

Fig. 2: Scatter Plot analysis of gene expression in VSMCs after 4 and $22 \mathrm{~h}$ treatment with AB serum (control) or with $\mathrm{AB}$ serum in the presence of LPS. The data points along the diagonal represent genes expressed at comparable levels in both samples whereas those that lie off the diagonal represent genes differentially expressed between the samples identified by the two axes. (A) LPS $4 \mathrm{hr}$ control (5\% AB serum, $4 \mathrm{~h}$ treatment) vs LPS $4 \mathrm{~h}$ treated (5\% AB serum $+100 \mathrm{ng} \mathrm{mL}^{-1}$ LPS, 4 hour treatment) (B) LPS $22 \mathrm{hr}$ control (5\% AB serum, $22 \mathrm{~h}$ treatment) vs LPS $22 \mathrm{hr}$ treated (5\% AB serum $+100 \mathrm{ng} \mathrm{mL}^{-1}$ LPS, $22 \mathrm{~h}$ treatment) (C) LPS $4 \mathrm{~h}$ control (5\% AB serum, $4 \mathrm{~h}$ treatment) vs LPS $22 \mathrm{hr}$ control (5\% AB serum, $22 \mathrm{~h}$ treatment) (D) LPS $4 \mathrm{~h}$ treated (5\% AB serum+100 $\mathrm{ng} \mathrm{mL}{ }^{-1}$ LPS, 4 hour treatment) vs LPS $22 \mathrm{hr}$ treated $\left(5 \% \mathrm{AB}\right.$ serum+100 $\mathrm{ng} \mathrm{mL} \mathrm{L}^{-1} \mathrm{LPS}$, $22 \mathrm{~h}$ treatment)

The expression of the top 10 down-regulated genes at $4 \mathrm{~h}$ had returned to near normal levels at $22 \mathrm{~h}$ and thus the profile of the genes repressed at $22 \mathrm{~h}$ was different from the genes repressed at $4 \mathrm{~h}$ (Table 1). Three of the top 10 genes that were most highly down-regulated in $22 \mathrm{~h}$ were signal transduction-related genes (KRAS2, PAK1IP1, SH3BP2). This group also contained genes involved in various functions such as transcription repression (HDAC4), ribosome macromolecular assembly (RPS10), cytochrome c oxidase respiratory chain complex (COX5), glycine metabolism (GCSH), actin polymerization and cell adhesion to extracellular matrix (ITGB5) and two hypothetical genes (C6orf79, KIAA0507).

Profile of up-regulated genes: SMC genes upregulated by LPS treatment may be associated with antibacterial or anti-viral activity and inflammation and/or the induction of the proliferative, migratory and synthetic phenotype. The top 10 up-regulated genes in SMC treated with LPS for $4 \mathrm{~h}$ were mostly LPS-, interferon-, TNF- or IL1-inducible proinflammatory and antiviral genes that participate in host defense (Table 2). The level of expression of many of the genes up-regulated at $4 \mathrm{~h}$ was found to have subsided by $22 \mathrm{~h}$. The gene that was most highly up-regulated in $4 \mathrm{~h}$ LPSstimulated SMCs was IFIT1. It has been suggested that IFIT1 is an anti-viral protein; however, its exact mechanism of action is at present unclear ${ }^{[32]}$. IFIT1 has recently been reported to bind to Rho guanine nucleotide exchange factor $10^{[33]}$ and also to block the interaction between eukaryotic translation initiation factors, eIF2 and eIF3 and thereby regulate translation initiation and protein synthesis ${ }^{[34]}$. IFIT4 which is a member of IFIT1 family of closely linked genes was also highly up-regulated ${ }^{[35]}$. Other genes encoding 
Am. J. Immunol., 3 (2): 56-73, 2007

Table 1: Ten SMC genes highly down-regulated by LPS treatment at $4 \mathrm{~h}(\mathrm{~A})$ and $22 \mathrm{~h}$ (B). (All numbers are expressed as signal log ratio.)

\begin{tabular}{llll}
\hline Symbol & LPS $4 \mathrm{~h}$ & LPS $22 \mathrm{~h}$ & Gene \\
\hline CNR1 & -3.5 & 1.3 & cannabinoid receptor 1 (brain) \\
ALB & -3.2 & 0 & albumin \\
HCAP-G & -3.1 & -1.1 & chromosome condensation protein G \\
GW112 & -3.1 & 0.1 & differentially expressed in hematopoietic lineages \\
PTGDR & -2.9 & 0.1 & prostaglandin D2 receptor (DP) \\
CLCN3 & -1.8 & 0.5 & chloride channel 3 \\
INHBE & -1.7 & -0.4 & activin beta E \\
D2LIC & -1.6 & -0.9 & dynein 2 light intermediate chain \\
PTGER4 & -1.6 & -0.6 & prostaglandin E receptor 4 (subtype EP4) \\
PPFIA3 & -1.4 & -1.9 & protein tyrosine phosphatase, receptor type, f polypeptide (PTPRF), interacting protein (liprin), alpha 3 \\
KRAS2 & -0.2 & -3.3 & v-Ki-ras2 Kirsten rat sarcoma 2 viral oncogene homolog \\
KIAA0507 & 0.3 & -2.4 & Homo sapiens mRNA, chromosome 1 specific transcript KIAA0507. \\
HDAC4 & 0.3 & -2.2 & histone deacetylase 4 \\
COX5A & -0.2 & -2.1 & cytochrome c oxidase subunit Va \\
PAK1IP1 & -0.1 & -2.1 & PAK1 interacting protein 1 \\
ITGB5 & 0.3 & -2 & integrin, beta 5 \\
SH3BP2 & 2.1 & -2 & SH3-domain binding protein 2 \\
GCSH & -0.2 & -1.9 & Homo sapiens transcribed sequence with strong similarity to protein pir:GCHUH (H.sapiens) GCHUH \\
& & & glycine cleavage system protein H precursor - human \\
C6orf79 & 0.1 & -1.9 & chromosome 6 open reading frame 79 \\
RPS10 & 0.3 & -1.9 & ribosomal protein S10 \\
\hline
\end{tabular}

Table 2. Ten SMC genes highly up-regulated by LPS treatment at $4 \mathrm{~h}(\mathrm{~A})$ and $22 \mathrm{~h}$ (B). (All numbers are expressed as signal log ratio.)

\begin{tabular}{llll}
\hline Symbol & LPS $4 \mathrm{~h}$ & LPS $22 \mathrm{~h}$ & Gene \\
\hline IFIT1 & 7.3 & 5 & interferon-induced protein with tetratricopeptide repeats 1 \\
USP18 & 4.3 & 5 & ubiquitin specific protease 18 \\
SAMHD1 & 3.9 & 3.1 & SAM domain and HD domain 1 \\
cig5 & 3.8 & 0.9 & viperin \\
MX1 & 3.7 & & myxovirus (influenza virus) resistance 1, interferon-inducible protein \\
p78 (mouse) & & & \\
MDA5 & 3.7 & 1.9 & melanoma differentiation associated protein-5 \\
IFIT4 & 3.6 & 1.6 & interferon-induced protein with tetratricopeptide repeats 4 \\
CCL3 & 3.6 & 4.3 & chemokine (C-C motif) ligand 3 \\
CCL20 & 3.4 & 2.6 & chemokine (C-C motif) ligand 20 \\
IFI44 & 3.4 & 7 & interferon-induced protein 44 \\
LOXL2 & 0.1 & 6.8 & lysyl oxidase-like 2 \\
POLR2E & 0 & 6.2 & polymerase (RNA) II (DNA directed) polypeptide E, 25kDa \\
C1orf2 & 3.1 & 6.1 & chromosome 1 open reading frame 29 \\
COL6A2 & -0.1 & 5.7 & collagen, type VI, alpha 2 \\
IFI27 & 2.4 & 5.7 & interferon, alpha-inducible protein 27 \\
TETRAN & -0.5 & 5.7 & tetracycline transporter-like protein \\
EMILIN1 & -0.7 & 5.6 & elastin microfibril interfacer 1 \\
MAZ & 0.2 & 5.4 & MYC-associated zinc finger protein (purine-binding transcription factor) \\
PLEC1 & -0.4 & 5.3 & plectin 1, intermediate filament binding protein 500kDa \\
BTBD2 & 0 & & BTB (POZ) domain containing 2 \\
\hline
\end{tabular}

antiviral proteins that were highly induced in $4 \mathrm{~h}$ include MX1, cig5 and MDA5. Pro-inflammatory cytokines and chemokines known to be induced in response to bacterial and viral infections (CCL3, CCL20) were upregulated in $4 \mathrm{~h}$ LPS-stimulated SMCs. Some of the cytokine up-regulated genes may not be directly involved in defense response and these include USP18 (deubiquitinating protease) ${ }^{[36]}$ and SAMHD1 (implicated in shifting dendritic cells from antigen uptake and processing phenotype to the antigen presentation phenotype $)^{[37]}$. Two cytokine inducible genes of unknown functions (IFIT4, IFI44) were also upregulated at $4 \mathrm{~h}$. The overall profile of the top 10 genes regulated in $4 \mathrm{~h}$ LPS-stimulated SMC is reminiscent of the induction of acute inflammation and a proliferative response.

In contrast with the profile of the genes induced by LPS in $4 \mathrm{~h}$, most of the genes up-regulated in $22 \mathrm{~h}$ were probably not the direct result of cytokine activity but rather the effects of induction or activation of transcription factors. The top 10 over-expressed genes were predominantly involved in transcriptional activation, extracellular matrix formation and cell proliferation. LOXL2, a copper-dependent enzyme that 
initiates cross-linking of collagens and elastin ${ }^{[38]}$, had the greatest expression among the top 10 highly upregulated genes in $22 \mathrm{~h}$ LPS-treated SMCs (Table 2). Recently a direct link has been established between LOXL2 and SNAIL, a transcription factor that represses E-cadherin expression, in inducing epithelialmesenchymal cell transitions and carcinoma $\operatorname{progression}^{[39]}$. Thus there is a possibility that the upregulated expression of LOXL2 in LPS treated SMC may be associated with the induction of the proliferative response. Several genes involved in extracellular matrix formation (COL6A2, EMILIN1, PLEC1) were also highly up-regulated. The other genes in the $22 \mathrm{~h}$ top 10 up-regulated category include genes involved in transcription regulation or chromatin modification (POLR2E, MAZ, BTBD2), IFN-inducible genes (IFI27), tetracyclin transporter-like protein (TETRAN) and the hypothetical C1orf29 gene.

Functional characterization of the LPS regulated genes: In order to discover the classes of genes that were involved in LPS-mediated SMC activation, we applied a signal $\log$ ratio cut-off of $> \pm 1.0$, eliminated all redundant probes that had less significant statistical values for each gene and categorized the remaining 1541 differentially regulated genes into functional groups/subgroups based on gene annotation information from Affymetrix database. Genes of unknown or miscellaneous functions were grouped together as Others. As shown in Figure 3, differential expression of genes belonging to functional categories such as transcription and chromatin remodeling, translation, signal transduction, host defense, proliferation, apoptosis, metabolism, ubiquitination, transporters and structural proteins indicates a robust SMC response to LPS treatment. The complete tables of the functional categories of LPS regulated SMC genes are available on request Table 3. A detailed discussion of all regulated genes is beyond the scope of this report and instead we focus on the specific sets of genes that are involved in host defense, transcription and chromatin remodeling, signal transduction, proliferation, apoptosis and cytoskeleton and matrix formation which we believe drive SMC phenotype modulation.

Host defense: Treatment of SMC with LPS induced the expression of several ligands and receptors of C-C and $\mathrm{C}-\mathrm{X}-\mathrm{C}$ chemokines and interleukins. Although the changes in the expression of various interferon subtypes were not deemed significant when analyzed using GCOS version 1.0, several interferon-inducible genes (IFIT1, IFIT2, IFIT4, IFI27, STIP1, G1P2, G1P3,

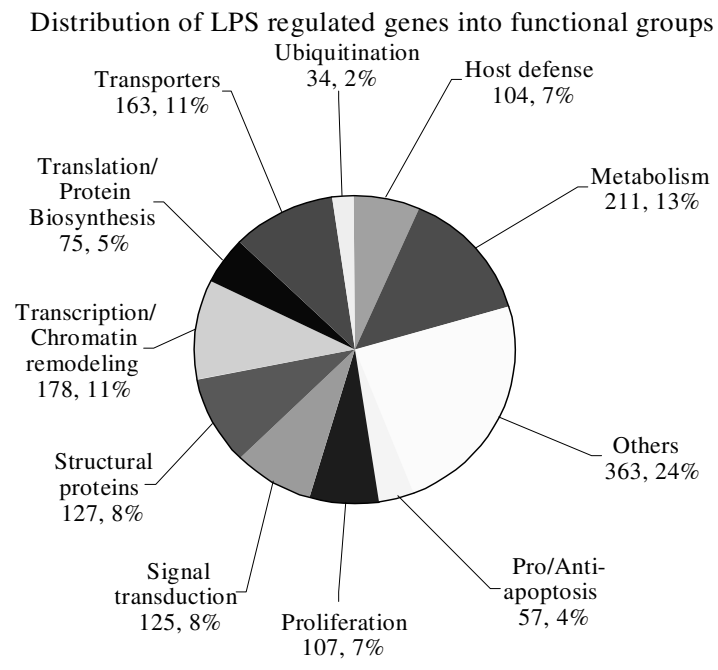

Fig. 3: Functional categories of LPS-regulated VSMC genes. We applied a signal log ratio cutoff of $>+1.0$ to all the genes that were differentially regulated by LPS treatment by $4 \mathrm{~h}$ and $22 \mathrm{~h}$ and all redundant probes that had less significant statistical values for each gene were also eliminated. Then the remaining 1541 differentially regulated genes were categorized into functional groups/subgroups based on gene annotation information from Affymetrix database. Genes of unknown or miscellaneous functions were grouped together as Others.

IFI44, IFI35, OAS1-3, MX1), granulocyte colony stimulating factor 3 (CSF3), neutrophil chemokines, IL8, CCL20, CCL3, CXCL3, CXCL10 and MIF were highly expressed. Other inflammatory and immunerelated genes such as the toll-interacting protein $(\mathrm{TOLLIP})^{[40]}$ and antiviral proteins (OAS1, 2, 3) were more up-regulated at $22 \mathrm{~h}$ compared to $4 \mathrm{~h}$. Serine proteinase inhibitor (SERPINB2) was induced possibly to protect the SMCs from excessive inflammation. Taken together, the results suggest that LPS induces SMCs to express inflammatory cytokines, chemokines and cell surface receptors that could induce chemotactic attraction of hematopoietic cells, neutrophils and mononuclear cells which contribute to inflammatory and immune responses. This is consistent with the well known function of LPS as a potent activator of inflammation and immune response.

Transcription and chromatin remodeling: LPS regulated the expression of many transcription factors and molecules involved in chromatin remodeling. The most highly up-regulated transcription-related gene was 
Am. J. Immunol., 3 (2): 56-73, 2007

Table 3. VSMC genes regulated by LPS treatment at 4 and $22 \mathrm{~h}$. (Gene expressions are shown in signal log ratio.)

\begin{tabular}{|c|c|c|c|c|}
\hline \multicolumn{5}{|c|}{ A. Genes involved in host defense } \\
\hline Probe Set ID & Gene & Symbol & $4 \mathrm{~h}$ & $22 \mathrm{~h}$ \\
\hline \multicolumn{5}{|l|}{ IFN Inducible } \\
\hline 202411_at & interferon, alpha-inducible protein 27 & IFI27 & 2.4 & 5.7 \\
\hline 203153_at & interferon-induced protein with tetratricopeptide repeats 1 & IFIT1 & 7.3 & 5 \\
\hline 212009_s_at & stress-induced-phosphoprotein 1 (Hsp70/Hsp90-organizing protein) & STIP1 & -0.1 & 4.6 \\
\hline 205483_s_at & interferon, alpha-inducible protein (clone IFI-15K) & G1P2 & 2.3 & 3.9 \\
\hline 202086_at & myxovirus (influenza virus) resistance 1 , interferon-inducible protein p78 (mouse) & MX1 & 3.7 & 3.8 \\
\hline 204972_at & 2'-5'-oligoadenylate synthetase $2,69 / 71 \mathrm{kDa}$ & OAS2 & 1.8 & 2.9 \\
\hline 205552_s_at & 2 ',5'-oligoadenylate synthetase $1,40 / 46 \mathrm{kDa}$ & OAS1 & 2.5 & 2.8 \\
\hline $217502 \_$at & interferon-induced protein with tetratricopeptide repeats 2 & IFIT2 & 2.3 & 2.8 \\
\hline 218400_at & 2'-5'-oligoadenylate synthetase $3,100 \mathrm{kDa}$ & OAS3 & 1.1 & 2.8 \\
\hline 204415_at & interferon, alpha-inducible protein (clone IFI-6-16) & G1P3 & 1.3 & 2.7 \\
\hline 214453_s_at & interferon-induced protein 44 & IFI44 & 3.4 & 2.6 \\
\hline 209417_s_at & interferon-induced protein 35 & IFI35 & 0.6 & 2 \\
\hline 204747_at & interferon-induced protein with tetratricopeptide repeats 4 & IFIT4 & 3.6 & 1.6 \\
\hline \multicolumn{5}{|c|}{ Innate Immunity and Inflammation } \\
\hline 205476_at & chemokine (C-C motif) ligand 20 & CCL20 & 3.4 & 4.3 \\
\hline 204614_at & serine (or cysteine) proteinase inhibitor, clade B (ovalbumin), member 2 & SERPINB2 & 1.3 & 3.2 \\
\hline 217871_s_at & macrophage migration inhibitory factor (glycosylation-inhibiting factor) & MIF & -0.1 & 2.9 \\
\hline 217930_s_at & toll interacting protein & TOLLIP & 0.1 & 2.8 \\
\hline 211506_s_at & interleukin 8 & IL8 & 1.9 & 2.6 \\
\hline 207442_at & colony stimulating factor 3 (granulocyte) & CSF3 & 2.6 & 1.6 \\
\hline 205114_s_at & chemokine (C-C motif) ligand 3 & CCL3 & 3.6 & 1.3 \\
\hline 204533_at & chemokine (C-X-C motif) ligand 10 & CXCL10 & 2.6 & 0.9 \\
\hline 207850_at & chemokine (C-X-C motif) ligand 3 & CXCL3 & 2.5 & 0.2 \\
\hline \multicolumn{5}{|c|}{ B. Genes involved in transcription and chromatin remodeling } \\
\hline \multicolumn{5}{|c|}{ Chromatin Remodeling } \\
\hline 207824_s_at & MYC-associated zinc finger protein (purine-binding transcription factor) & MAZ & 0.2 & 5.6 \\
\hline 218045_x_at & parathymosin & PTMS & -0.1 & 4.9 \\
\hline 218064_s_at & neighbor of A-kinase anchoring protein 95 & NAKAP95 & -0.3 & 4.9 \\
\hline 204805_s_at & H1 histone family, member $\mathrm{X}$ & H1FX & -1.1 & 4 \\
\hline 208180_s_at & histone $1, \mathrm{H} 4 \mathrm{~h}$ & HIST1H4H & 1.5 & 3 \\
\hline 207645_s_at & chromodomain helicase DNA binding protein 1-like & CHD1L & 0.3 & 3 \\
\hline 208527_x_at & histone $1, \mathrm{H} 2 \mathrm{be}$ & HIST1H2BE & -0.1 & 2.4 \\
\hline 214290_s_at & histone 2, H2aa & HIST2H2AA & 0 & 2.3 \\
\hline \multicolumn{5}{|c|}{ Transcription Regulation } \\
\hline 209636_at & nuclear factor of kappa light polypeptide gene enhancer in B-cells 2 (p49/p100) & NFKB2 & 0.7 & 4 \\
\hline 209878_s_at & $\begin{array}{l}\text { v-rel reticuloendotheliosis viral oncogene homolog A, nuclear factor of kappa } \\
\text { light polypeptide gene enhancer in B-cells } 3 \text {, p } 65 \text { (avian) }\end{array}$ & RELA & 0.4 & 3.9 \\
\hline 201332_s_at & signal transducer and activator of transcription 6 , interleukin- 4 induced & STAT6 & 0.4 & 3 \\
\hline 208436_s_at & interferon regulatory factor 7 & IRF7 & 1.5 & 2.5 \\
\hline \multicolumn{5}{|l|}{ Basal TF } \\
\hline 213887_s_at & polymerase (RNA) II (DNA directed) polypeptide E, $25 \mathrm{kDa}$ & POLR2E & 0 & 6.8 \\
\hline 203239_s_at & CCR4-NOT transcription complex, subunit 3 & CNOT3 & -0.2 & 4.1 \\
\hline 215357_s_at & polymerase delta interacting protein 46 & PDIP46 & 0.3 & 3.6 \\
\hline 202996_at & polymerase (DNA-directed), delta 4 & POLD4 & 0 & 3.5 \\
\hline 208960_s_at & core promoter element binding protein & COPEB & 0.6 & 2.6 \\
\hline 205966_at & TAF13 RNA polymerase II, TATA box binding protein (TBP)-associated factor, 18kDa & TAF13 & 0 & 2.6 \\
\hline 210892_s_at & general transcription factor II, i & GTF2I & -0.2 & 2.2 \\
\hline \multicolumn{5}{|c|}{ C. Genes involved in signal transduction } \\
\hline \multicolumn{5}{|l|}{ MAPK } \\
\hline 213490_s_at & mitogen-activated protein kinase kinase 2 & MAP2K2 & 0.2 & 4 \\
\hline 215050_x_at & mitogen-activated protein kinase-activated protein kinase 2 & MAPKAPK2 & 0 & 3.2 \\
\hline \multicolumn{5}{|l|}{ RAS } \\
\hline 209991_x_at & G protein-coupled receptor 51 & GPR51 & -0.6 & 5.2 \\
\hline 215807_s_at & plexin B1 & PLXNB1 & 0 & 4.9 \\
\hline $\begin{array}{l}207419 \_s \_a t \\
4.4\end{array}$ & \multicolumn{2}{|l|}{ ras-related C 3 botulinum toxin substrate 2 (rho family, small GTP binding protein Rac2) } & RAC2 & 0.5 \\
\hline 217782_s_at & G protein pathway suppressor 1 & GPS1 & -0.3 & 3.9 \\
\hline 203267_s_at & developmentally regulated GTP binding protein 2 & DRG2 & -0.1 & 3.7 \\
\hline 208009_s_at & Rho guanine exchange factor (GEF) 16 & ARHGEF16 & 0.1 & 3.4 \\
\hline 201167_x_at & Rho GDP dissociation inhibitor (GDI) alpha & ARHGDIA & 0.8 & 3.2 \\
\hline
\end{tabular}


Am. J. Immunol., 3 (2): 56-73, 2007

\begin{tabular}{|c|c|c|c|c|}
\hline 206971_at & G protein-coupled receptor 161 & GPR161 & 0.5 & 3.1 \\
\hline 203136_at & Rab acceptor 1 (prenylated) & RABAC1 & 0.1 & 2.7 \\
\hline 215249_at & mucin 20 & MUC20 & 0.1 & 2.2 \\
\hline 212932_at & RAB3 GTPase-ACTIVATING PROTEIN & RAB3GAP & -0.3 & 2.1 \\
\hline 206673_at & putative $\mathrm{G}$ protein coupled receptor & GPR & -0.1 & 2 \\
\hline 200852_X_at & guanine nucleotide binding protein ( $\mathrm{G}$ protein), beta polypeptide 2 & GNB2 & -0.4 & 2 \\
\hline \multicolumn{5}{|l|}{ PI3K } \\
\hline 210969_at & protein kinase $\mathrm{C}$-like 2 & PRKCL2 & 0.3 & 3.9 \\
\hline 202545_at & protein kinase $\mathrm{C}$, delta & PRKCD & -1.8 & 3.8 \\
\hline 210417_s_at & phosphatidylinositol 4-kinase, catalytic, beta polypeptide & PIK4CB & -0.2 & 2.2 \\
\hline \multicolumn{5}{|c|}{$\begin{array}{l}1 \\
\end{array}$} \\
\hline 58994_at & putative NFkB activating protein & FLJ20241 & -0.2 & 2.7 \\
\hline 214398_s_at & inhibitor of kappa light polypeptide gene enhancer in B-cells, kinase epsilon & IKBKE & 0.2 & 2.3 \\
\hline \multicolumn{5}{|l|}{ TGFB Related } \\
\hline 203085_s_at & transforming growth factor, beta 1 (Camurati-Engelmann disease) & TGFB1 & -0.3 & 3.3 \\
\hline 209920_at & bone morphogenetic protein receptor, type II (serine/threonine kinase) & BMPR2 & -0.4 & 2 \\
\hline \multicolumn{5}{|c|}{ D. Genes involved in proliferation } \\
\hline \multicolumn{5}{|l|}{ Cell Cycle } \\
\hline 221427_s_at & cyclin L2 & CCNL2 & 0 & 5.1 \\
\hline 204247_s_at & cyclin-dependent kinase 5 & CDK5 & -0.6 & 4.3 \\
\hline 204857_at & MAD1 mitotic arrest deficient-like 1 (yeast) & MAD1L1 & -0.8 & 3.7 \\
\hline 211017_s_at & neurofibromin 2 (bilateral acoustic neuroma) & NF2 & -0.4 & 3.5 \\
\hline 209754_s_at & thymopoietin & TMPO & 0.1 & 3.1 \\
\hline 207428_x_at & cell division cycle 2 -like 2 & $\mathrm{CDC} 2 \mathrm{~L} 2$ & -0.4 & 2.8 \\
\hline 203252_at & tumor suppressor deleted in oral cancer-related 1 & DOC-1R & 0 & 2.7 \\
\hline 209414_at & Fzr1 protein & FZR1 & 0.5 & 2.4 \\
\hline 210622_x_at & cyclin-dependent kinase (CDC2-like) 10 & CDK10 & 0.2 & 2.4 \\
\hline 209953_s_at & CDC37 cell division cycle 37 homolog (S. cerevisiae) & $\mathrm{CDC} 37$ & -0.4 & 2.4 \\
\hline 208721_s_at & anaphase promoting complex subunit 5 & ANAPC5 & -0.2 & 2.3 \\
\hline 216277_at & BUB1 budding uninhibited by benzimidazoles 1 homolog (yeast) & BUB1 & 1.4 & 2 \\
\hline 209112_at & cyclin-dependent kinase inhibitor 1B (p27, Kip1) & CDKN1B & -1.2 & -0.7 \\
\hline 204170_s_at & CDC28 protein kinase regulatory subunit 2 & CKS2 & -0.2 & -1 \\
\hline 202284_s_at & cyclin-dependent kinase inhibitor 1A (p21, Cip1) & CDKN1A & -0.3 & -1 \\
\hline 204159_at & cyclin-dependent kinase inhibitor 2C (p18, inhibits CDK4) & $\mathrm{CDKN} 2 \mathrm{C}$ & -0.7 & -1 \\
\hline 207039_at & cyclin-dependent kinase inhibitor 2A (melanoma, p16, inhibits CDK4) & CDKN2A & -0.1 & -1.6 \\
\hline \multicolumn{5}{|c|}{ GF and Angiogenesis } \\
\hline 219922_s_at & latent transforming growth factor beta binding protein 3 & LTBP3 & -0.5 & 4.5 \\
\hline 207334_s_at & transforming growth factor, beta receptor II $(70 / 80 \mathrm{kDa})$ & TGFBR2 & 0.6 & 4 \\
\hline 208231_at & neuregulin 1 & NRG1 & -0.1 & 2.9 \\
\hline 206796_at & WNT1 inducible signaling pathway protein 1 & WISP1 & -0.3 & 2.9 \\
\hline 206814_at & nerve growth factor, beta polypeptide & NGFB & 0.8 & 2.6 \\
\hline 210513_s_at & vascular endothelial growth factor & VEGF & 0.4 & 2.6 \\
\hline 210973_s_at & fibroblast growth factor receptor 1 (fms-related tyrosine kinase 2 , Pfeiffer syndrome) & FGFR1 & 0.3 & 2.2 \\
\hline 213807_x_at & met proto-oncogene (hepatocyte growth factor receptor) & MET & 0.9 & 2 \\
\hline 202290_at & PDGFA associated protein 1 & PDAP1 & 0.2 & 2 \\
\hline \multicolumn{5}{|l|}{ Differentiation } \\
\hline 210756_s_at & Notch homolog 2 (Drosophila) & NOTCH2 & 0.6 & 2 \\
\hline \multicolumn{5}{|l|}{ Others } \\
\hline 200001_at & calpain, small subunit 1 & CAPNS1 & -0.2 & 2.7 \\
\hline 218663_at & chromosome condensation protein $\mathrm{G}$ & HCAP-G & -3.1 & -1.1 \\
\hline \multicolumn{5}{|c|}{ E. Genes involved in apoptosis } \\
\hline \multicolumn{5}{|l|}{ Pro-apoptotic } \\
\hline 211833_s_at & BCL2-associated X protein & BAX & -0.2 & 4.1 \\
\hline 214667_s_at & tumor protein $\mathrm{p} 53$ inducible protein 11 & TP53I11 & 0.6 & 3.8 \\
\hline 209941_at & receptor (TNFRSF)-interacting serine-threonine kinase 1 & RIPK1 & -0.1 & 3.6 \\
\hline 1861_at & BCL2-antagonist of cell death & BAD & 0.1 & 3.2 \\
\hline 206133_at & XIAP associated factor- 1 & HSXIAPAF1 & 1.2 & 2.4 \\
\hline 203890_s_at & death-associated protein kinase 3 & DAPK3 & -0.1 & 2 \\
\hline 214617_at & perforin 1 (pore forming protein) & PRF1 & -0.6 & 2 \\
\hline 219209_at & melanoma differentiation associated protein- 5 & MDA5 & 3.7 & 1.9 \\
\hline 220518_at & target of Nesh-SH3 & TARSH & 2 & 0.8 \\
\hline \multicolumn{5}{|l|}{ Anti-apoptotic } \\
\hline 200796_s_at & myeloid cell leukemia sequence 1 (BCL2-related) & MCL1 & 0.7 & 5 \\
\hline 210538_s_at & baculoviral IAP repeat-containing 3 & BIRC3 & 2.7 & 4.9 \\
\hline
\end{tabular}


Am. J. Immunol., 3 (2): 56-73, 2007

\begin{tabular}{|c|c|c|c|c|}
\hline 218813_s_at & SH3-domain GRB2-like endophilin B2 & SH3GLB2 & 0 & 2.9 \\
\hline 211546_x_at & synuclein, alpha (non A4 component of amyloid precursor) & SNCA & 0.8 & 2 \\
\hline 218943_s_at & DEAD/H (Asp-Glu-Ala-Asp/His) box polypeptide & RIG-I & 3.4 & 1.6 \\
\hline 202510_s_at & tumor necrosis factor, alpha-induced protein 2 & TNFAIP2 & 2.6 & 1.2 \\
\hline 205681_at & BCL2-related protein A1 & BCL2A1 & 2.6 & 0.6 \\
\hline 212768_s_at & differentially expressed in hematopoietic lineages & GW112 & -3.1 & 0.1 \\
\hline \multicolumn{5}{|l|}{ TNF Related } \\
\hline 210654_at & $\begin{array}{l}\text { tumor necrosis factor receptor superfamily, member } 10 \mathrm{~d} \text {, } \\
\text { decoy with truncated death domain }\end{array}$ & TNFRSF10D & 0.3 & 4.1 \\
\hline 206508_at & tumor necrosis factor (ligand) superfamily, member 7 & TNFSF7 & 2.9 & 1.2 \\
\hline 202688_at & tumor necrosis factor (ligand) superfamily, member 10 & TNFSF10 & 2.1 & -0.3 \\
\hline \multicolumn{5}{|c|}{ F. Genes involved in structural proteins } \\
\hline \multicolumn{5}{|l|}{ ECM } \\
\hline 202997_s_at & lysyl oxidase-like 2 & LOXL2 & 0.1 & 7 \\
\hline 209156_s_at & collagen, type VI, alpha 2 & COL6A2 & -0.1 & 6.1 \\
\hline 204163_at & elastin microfibril interfacer 1 & EMILIN1 & -0.7 & 5.7 \\
\hline 217430_x_at & collagen, type I, alpha 1 & COL1A1 & 0.5 & 5.1 \\
\hline 212091_s_at & collagen, type VI, alpha 1 & COL6A1 & 0.2 & 4.7 \\
\hline 211966_at & collagen, type IV, alpha 2 & COL4A2 & 0 & 4.7 \\
\hline 201654_s_at & heparan sulfate proteoglycan 2 (perlecan) & HSPG2 & 0.6 & 4.5 \\
\hline 201262_s_at & biglycan & BGN & 0.7 & 4.4 \\
\hline 202827_s_at & matrix metalloproteinase 14 (membrane-inserted) & MMP14 & 0.7 & 4.3 \\
\hline 201286_at & syndecan 1 & SDC1 & 0.1 & 3.4 \\
\hline 209561_at & thrombospondin 3 & THBS3 & -0.1 & 2.6 \\
\hline 205746_s_at & $\begin{array}{l}\text { a disintegrin and metalloproteinase domain } 17 \\
\text { (tumor necrosis factor, alpha, converting enzyme) }\end{array}$ & ADAM17 & 0.1 & \\
\hline \multicolumn{5}{|l|}{ Cytoskeleton } \\
\hline 216971_s_at & plectin 1 , intermediate filament binding protein $500 \mathrm{kDa}$ & PLEC1 & -0.4 & 5.4 \\
\hline 209372_x_at & tubulin, beta polypeptide & TUBB & 0 & 4.3 \\
\hline 214040_s_at & gelsolin (amyloidosis, Finnish type) & GSN & 0.2 & 4.2 \\
\hline 214752_x_at & filamin A, alpha (actin binding protein 280) & FLNA & -0.3 & 3.3 \\
\hline 217817_at & actin related protein $2 / 3$ complex, subunit $4,20 \mathrm{kDa}$ & ARPC4 & -0.2 & 3.2 \\
\hline 210978_s_at & transgelin 2 & TAGLN2 & 0.2 & 3.1 \\
\hline 215074_at & myosin IB & MYO1B & -1.3 & 3 \\
\hline 220800_s_at & tropomodulin 3 (ubiquitous) & TMOD3 & 0 & 2.1 \\
\hline \multicolumn{5}{|c|}{ Adhesion and Migration } \\
\hline 217234_s_at & villin 2 (ezrin) & VIL2 & -0.1 & 3.9 \\
\hline 218182 s_at & claudin 1 & CLDN1 & 1.1 & 2.7 \\
\hline 209693_at & astrotactin 2 & ASTN2 & -0.7 & 2.7 \\
\hline 204627_s_at & integrin, beta 3 (platelet glycoprotein IIIa, antigen CD61) & ITGB3 & 0.2 & 2.6 \\
\hline 207788_s_at & vinexin beta (SH3-containing adaptor molecule-1) & SCAM-1 & 0.4 & 2.5 \\
\hline 200808_s_at & zyxin & ZYX & -0.1 & 2.4 \\
\hline 202071_at & syndecan 4 (amphiglycan, ryudocan) & SDC4 & 1 & 2.3 \\
\hline 210841_s_at & neuropilin 2 & NRP2 & 0.6 & 2.2 \\
\hline 215836_s_at & protocadherin gamma subfamily C, 3 & PCDHGC3 & 0.3 & 2.1 \\
\hline 206908_s_at & claudin 11 (oligodendrocyte transmembrane protein) & CLDN11 & 0.3 & 2.1 \\
\hline 202638_s_at & intercellular adhesion molecule 1 (CD54), human rhinovirus receptor & ICAM1 & 1.7 & 2 \\
\hline 204306_s_at & CD151 antigen & CD151 & 0 & 2 \\
\hline 208850_s_at & Thy- 1 cell surface antigen & THY1 & 0 & 2 \\
\hline
\end{tabular}

RNA polymerase II polypeptide E (POLR2E), a component of the multisubunit eukaryotic DNAdependent RNA polymerase II complex ${ }^{[41]}$. Several other components of the POLR2 holoenzyme were upregulated. These include DNA polymerases (PDIP46, POLD4), core promoter binding proteins (COPEB, TAF13), initiator binding protein (GTF2I) and transcription complex subunit 3 (CNOT3).

Parathymosin (PTMS) and chromodomain helicase DNA binding proteins (CHD1L) and several nucleosomal histones (H1FX, HIST1H4H, HISTH2BE,
HIST2H2AA) were highly up-regulated in LPS-treated cells. Particularly PTMS affects the interaction of linker histone $\mathrm{H} 1$ which is the major factor that stabilizes higher order chromatin structure with nucleosomes and thereby modulates the action of chromatin-remodeling enzymes $^{[42]}$. Zinc finger protein transcriptional regulators (NAKAP95 and MAZ) and members of NF$\mathrm{kB}$ family (NFKB2, RELA) were induced at $22 \mathrm{~h}$. IRF7 (a regulatory factor of viral/interferon inducible genes) and a member of the STAT family of transcription activators (STAT 6) were induced at $22 \mathrm{~h}$. These results 
are in agreement with previous reports of activation of the JAK-STAT signaling pathway in LPS treated cells. The above compendium of LPS-mediated differential expression of several chromatin remodeling genes and transcription regulators have profound effects on gene expression in LPS treated SMCs and subsequently on inflammation, proliferation, apoptosis, ECM production, cell adhesion and cell migration responses and the modulation of the quiescent cells to the activated SMC phenotype.

Signal transduction: Several genes involved in a variety of signal transduction pathways were upregulated in SMCs following treatment with LPS for 22 h. The Ras/Rho/CDC42 signaling pathway was activated as judged by the increase in the expression of genes encoding Rho guanine nucleotide exchange factors and dissociation inhibitors (ARHGEF16, ARHGDIA), G-protein coupled receptors (GPR, GPR51, GPR161, MUC20) and GTP-binding proteins of the Ras superfamily (GNB2, GPS1, DRG2, RABAC1, RAB3GAP, RAC2). Plexin B1 (PLXNB1) was the second highest induced gene in this category. PLXNB1 has been reported to mediate Sema4Dinduced repulsive axon guidance signaling by acting as a GTPase activating protein for R-Ras, a member of the Ras superfamily of small GTP-binding proteins, which plays a key role in cell adhesion by activating integrins and promoting cell migration and neurite outgrowth $^{[43,44]}$.

The transforming growth factor signaling pathway was recruited as judged by the induction of TGFB1, TGFBR2, LTBP3 and BMPR2. Binding of TGFB or BMPs to cognate type II receptors leads to the phosphorylation of the type I subunit by the constitutively active serine-threonine kinase type II receptor. Phosphorylated receptor $\mathrm{I}$ is an active kinase that subsequently phosphorylates and propagates intracellular downstream signals, including Smad proteins and mitogen-activated protein kinases ${ }^{[45,46]}$. By the regulation of TGF inducible genes, the TGFB signaling pathway may mediate regulatory effects on a multitude of cellular processes in the LPS-treated SMCs including proliferation, differentiation, migration and extracellular matrix accumulation ${ }^{[47]}$.

LPS also stimulated the expression of several transcriptional activators. The NF-kB subunits NFKB2 (p49/p100) and RELA (p65) as well as a putative NF$\mathrm{kB}$ activating protein (FLJ20241) and an inhibitor of inducible I-kappa B-kinase epsilon (IKBKE) were upregulated and their activation suggests NFkB pathway signaling ${ }^{[48]}$. The MAPK pathway was activated in LPS- treated SMCs as judged by the increased expression of MAPK enzymes ${ }^{[48]}$ (MAP2K2, MAPKAPK2). The phosphatidylinositol-3-kinase (PI3K) signaling pathway was also activated as judged by the increased expression of PIK4CB and protein kinase isotypes (PRKCD, PRKCL2).

Proliferation: Several growth factor genes (including VEGF, NRG1, NGFB) and growth factor receptor genes (e.g. FGFR1, MET, PDAP1) were induced by LPS at $22 \mathrm{~h}$. In mammals, the progression through the cell cycle is regulated by the association of cyclins and their cyclin-dependent kinase (CDK) partners. Activity of these cyclin/cyclin-dependent kinase complexes is inhibited by the action of cyclin-dependent kinase inhibitors (CDKIs) that bind to these complexes and thereby inhibit progression through the restriction points of the cell cycle and cellular proliferation. Treatment of SMCs with LPS for $22 \mathrm{~h}$ resulted in upregulation of several cell cycle-dependent genes (CCNL2, CDC2L2, CDC37, CDK5, CDK10), cell cycle regulatory genes (BUB1, human DOC-1R, NF2, FZR1, WISP1) and regulators of proliferation (MAD1L1, TMPO, CAPNS1, ANAPC5, NOTCH2). In contrast, negative regulators of growth such as cell cycle arrest genes including HCAP-G (mitosis-related chromosome condensation protein G), MAD1L1 (a G1 to $S$ cell cycle checkpoint protein) and several cyclindependent kinase inhibitors (CKS2, p27, p21, p18, p16) were repressed at $4 \mathrm{~h}$. These results are consistent with the pro-proliferative effect of LPS on SMCs.

Apoptosis: Six anti-apoptotic genes (BIRC3, RIG-I, BCL2A1, TNFAIP2, TNFSF7, TNFSF10) and 3 proapoptotic genes (HSXIAPAF1, MDA5, TARSH) were up-regulated within $4 \mathrm{~h}$ of LPS treatment whereas GW112 were repressed at $4 \mathrm{~h}$. Pro-apoptotic genes such as BAX, RIPK1, TP53I11, BAD, DAPK3, PRF1, MCL1, SH3GLB2, SNCA and TNFRSF10D were induced at $22 \mathrm{~h}$ and HSXIAPAF1 was induced at both 4 and $22 \mathrm{~h}$.

Structural proteins: The changes in expression levels of structural genes occurred predominantly at $22 \mathrm{~h}$. Among the up-regulated genes, extracellular matrix collagen 6A2, 6A1, 1A1 and 4A2 were greatly increased. The different types of collagens i) may be associated with laminin, entactin and heparan sulfate proteoglycans to form the sheet-like basement membranes that separate epithelium from connective tissue or ii) may be components of microfibrillar structures in many tissues that localize close to cells 
where they may provide an anchoring function and may be involved in cell migration, differentiation and embryonic development. Several non-collagenous ECM components were also up-regulated. LOXL2, a copperdependent enzyme that initiates cross-linking of collagens and elastin, was among the highly upregulated structural genes in $22 \mathrm{~h}$ LPS-treated SMCs (Table 1B). Genes encoding microfibril associated proteins (EMILIN1, THBS3) and heparin sulfate proteoglycans of basement membranes (HSPG2, BGN, SDC1, SDC4) were also up-regulated at $22 \mathrm{~h}$. These proteins may play a role in cell adhesion, cell morphology, intracellular communication and anchorage of SMC to elastic lamellae. The expression of several genes encoding cytoplasmic cytoskeletal proteins involved in actin reorganization (PLEC1, TUBB, GSN, NF2, VIL2, FLNA, ARPC4, TAGLN2, MYO1B, NRP2, TMOD3) were up-regulated after $22 \mathrm{~h}$ of LPS stimulation. These cytoskeletal proteins are central to the modulation of cell shape, adhesion, migration and the organization of cell surface structures.

Cell adhesion is an essential requirement for cell migration and morphogenesis during development. Genes encoding integral membrane proteins localized at focal adhesions and cell-cell junctions, such as VIL2, ASTN2, CLDN1, CLDN11, ITGB3, SCAM-1, ZYX, PCDHGC3, THY1, CD151, ICAM1 were up-regulated at $22 \mathrm{~h}$ in LPS stimulated SMCs. These proteins regulate a variety of cellular events, including cell adhesion, spreading and migration, cell proliferation and differentiation and anchorage dependence of signal transduction that may lead to cell proliferation, migration or transformation and metastasis ${ }^{[49,50,51]}$. Secretory metalloproteinases (such as MMP14, ADAM17) which are $\mathrm{Zn}(2+)$-binding endopeptidases that degrade various components of the extracellular matrix such as collagens, pro-collagens and hyaluronan binding proteoglycans and probably facilitate SMC migration were over-expressed in LPS stimulated SMC.

Studies using the candidate gene approach has shown that bacterial lipopolysaccharide induces differential induction of the expression of several VSMC genes that encode cytokines (IL-1 ${ }^{[52]}$, IL- $6^{[53]}$, TNF-alpha ${ }^{[54]}$, IFN ${ }^{[55]}$ ), chemokines (MCP- $1^{[56]}$, IP$10^{[57]}$, IL-8, MIP-2 ${ }^{[58]}$, enzymes involved in prostanoid synthesis (PLA2 ${ }^{[59]}, \mathrm{COX}-2^{[60]}$ ), adhesion molecules

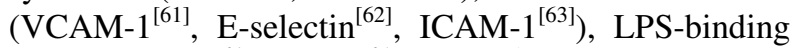
proteins $\left(\mathrm{LBP}^{[64]}, \mathrm{CD} 14^{[65]}\right.$, TLR $4^{[17]}$ ), human antigen $\mathrm{R}^{16}$ (an RNA-binding protein involved in LPS cell activation effects), adrenomedullin ${ }^{[66]}$, heme oxygenase$1^{[67]}$, low-density lipoprotein receptor-1 (LOX-1 $)^{[68]}$, complement components and regulators $(\mathrm{C} 3, \mathrm{C} 4, \mathrm{DAF}$,
MCP, CD59 $\left.9^{[69]}\right)$, iNOS $^{[70]}$ and NO production ${ }^{[71]}$, endothelin-receptor $\mathrm{A}$ and $\mathrm{B}^{[72]}$, antiviral cytomegalovirus inducible gene 5 (viperin) ${ }^{[73]}$, tissue factor and urokinase-type plasminogen activator (uPA) ${ }^{[74]}$. LPS has also been shown to mediate some of its effects by the regulation of cytokines ${ }^{[55]}$, activation of NADPH oxidase ${ }^{[17]}$ and MAPK ${ }^{[17,75]}$ and NFKB $^{[70]}$ signaling pathways. The data reported in this study is in agreement with most of these findings and also provides a comprehensive list of genes that have thus far not been implicated in LPS biology.

Clustering analysis of genes displaying similar expression: Differentially regulated genes were grouped according to their expression patterns following treatment with $\mathrm{AB}(4 \mathrm{~h}), \mathrm{AB}+\mathrm{LPS}(4 \mathrm{~h}), \mathrm{AB}$ $(22 \mathrm{~h})$ and $\mathrm{AB}+\mathrm{LPS}(22 \mathrm{~h})$ to determine if a correlation exists between gene function and expression pattern in response to LPS stimulation. Gene expression pattern analysis was performed using GENESIS ver. 1.3.0. Raw expression values of all differentially regulated genes (above signal log ratio of 1.0) from microarray analysis were adjusted with 'log 2 transform data' and 'median centre genes' and clustered into 40 groups using k-mean clustering. We focused on regulation at $4 \mathrm{~h}$ because we reasoned that this early time period may better represent direct signaling effect of LPS on gene transcription. Clusters with similar gene expression pattern were combined together to generate 3 groups: up-regulated at both 4 and $22 \mathrm{~h}$, up-regulated at $4 \mathrm{~h}$ and down-regulated at $4 \mathrm{~h}$. Detailed results of clustering analysis are available on request.

The majority of 83 genes up-regulated at both 4 and $22 \mathrm{~h}$ are IFN- or TNF-inducible genes (IFI-15K, IFIT1, IFN p78, IFNAI27, IFNR2, ISTF3, IFNIP44, IFIT4, OAS1-3, IRF7, TNFSF7, 10, TNFAIP2, etc.) or cytokine/chemokine genes (CCL3, CXCL3, CSF3, CXCL10, CCL8, IL8, etc.) associated with the inflammatory response. This observation re-emphasizes the important role of LPS in the regulation of SMC activation and phenotype modulation and the initiation and/or augmentation of inflammation in cardiovascular diseases.

Fourteen out of 41 genes in the $4 \mathrm{~h}$ up-regulated group belong to a subgroup containing growth factors (FGF2, BMP2, LIM), cytokines (IL-1b, IL-15) and cytokine-induced genes (IFIT5, VCAM1, TNFAIP6, IKKa, CC2, CC7, CXC11, OASL, SOD2). The $4 \mathrm{~h}$ down-regulated gene group (116 genes) contained genes that mediate diverse biological functions such as chromosomal modification, signal transduction, growth and differentiation, metabolism, translation, and nuclear transport. 
siRNA knockdown of IFIT1: Since IFIT1 was an early response gene that was most dramatically induced by LPS, we hypothesized that it may have an important role in the early events of the activation and proliferation of SMCs. Thus to gain insight into the biological significance of IFIT1 in LPS-induced SMCs, we knocked down IFIT1 transcripts using small interference RNA and then compared the expression of candidate genes in knock-down cells with wild type cells using real-time PCR. Human aortic SMCs (T/G HA-VSMC) were transfected with scrambled siRNA or IFIT1 siRNA as described and IFIT1 expression was assessed using semi-quantitative RT-PCR. Aliquots of the amplification mixtures were collected after 25, 30 and 35 cycles and analyzed by $1 \%$ agarose gel electrophoresis. IFIT1 expression was almost completely suppressed by siRNA relative to scrambled siRNA control (data not shown). To gain further insight into the biological functions of IFIT1, the effect of IFIT1 knock-down on the expression of 14 different candidate genes such as IFIT1, IFIT4, FOS, B2M, cytokines (TNF, TGF $\beta$ ), adhesion molecules (ICAM1, VCAM), cell cycle progression/control (CCND1, p53, $\mathrm{p} 15, \mathrm{p} 16, \mathrm{p} 21, \mathrm{p} 27)$ was analyzed. The expression of each gene in IFIT1 knock-down (KD) SMCs was calculated relative to the expression level in control cells treated with the scrambled siRNA, which was taken as $100 \%$. The expression of IFIT1 in SMC IFIT1 knock-down SMCs was reduced to $8 \%$ and interestingly the expression of the closely linked paralogous gene, IFIT4, was also coordinately down-regulated to $35 \%$ (Fig. 4A). The expression of TGF $\beta$, ICAM1, VCAM, $\mathrm{p} 15, \mathrm{p} 16, \mathrm{p} 27$ and B2M was not significantly affected by IFIT1 KD. While TNF was moderately downregulated to $65 \%$ (Fig. 4A), IFIT1 knock-down resulted in a remarkable up-regulation of FOS ( 8 fold), TP53 (11 fold), CDKN1A/p21 (866 fold) (Fig. 4B). The human c-fos oncogene heterodimerizes with $\mathrm{c}$-jun to form the immediate-early transcription factor AP-1 that stimulates the transcription of genes containing AP-1 regulatory elements ${ }^{[76]}$. The tumor suppressor protein, TP53, which is undetectable or present in low levels in resting cells but is generally found in increasing amounts in proliferating non-transformed and transformed cells, is up-regulated in response to stress signals, DNA damage and is transcriptionally induced by IFNA/B through ISGF $3^{[77]}$. It has been proposed that TP53 binds as a tetramer to a p53-binding site and activates the transcription of downstream target genes that induce apoptosis or cell cycle arrest and/or invasion ${ }^{[78,79]}$. The cyclin-dependent kinase inhibitor, $\quad$ CDKN1A/p21,
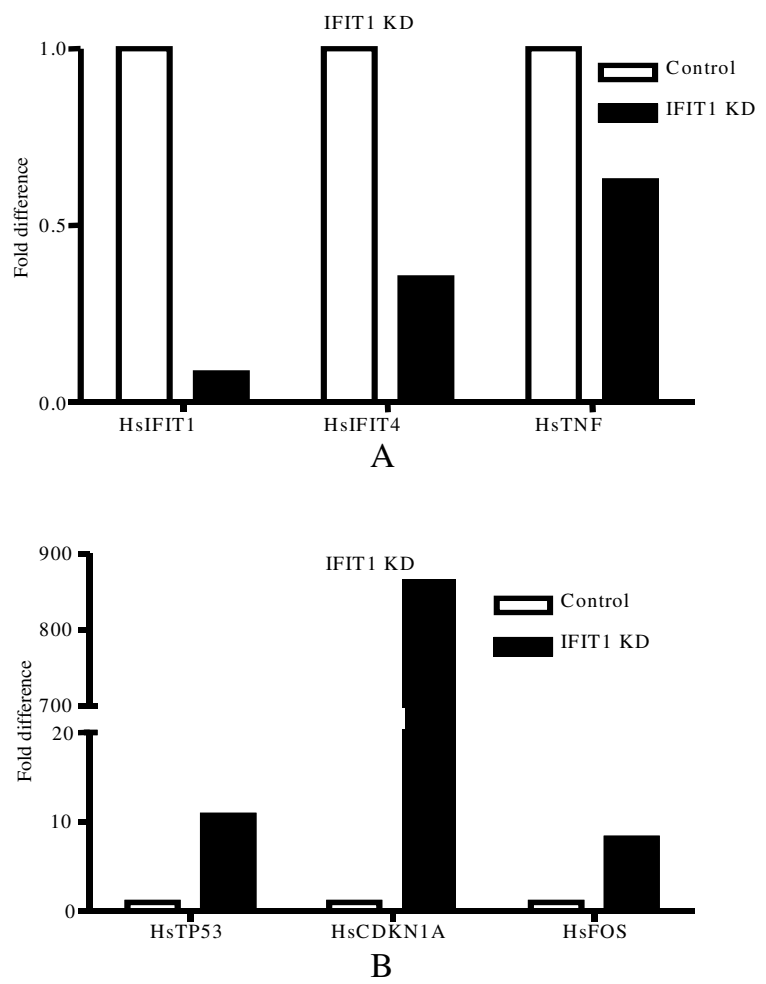

Fig. 4: Effect of IFIT1 knock-down on VSMC gene expression. The expression of IFIT1 was knocked down using a siRNA specific to IFIT1 (IFIT1 KD-black bars) and a scrambled siRNA as a control (Control-white bars). The expression of candidate genes was measured using real-time quantitative PCR. (A) The effect of IFIT1 knock-down on the expression of IFIT1, IFIT4, TNF. (B) The effect of IFIT1 knock-down on the expression of TP53, CDKN1A, FOS.

participates in the regulation of the G2 checkpoint of the cell cycle and probably serves as the effector of TP53 cell cycle control ${ }^{[76]}$. The up-regulation of these genes in IFIT1 knock-down cells suggests that IFIT1 may be implicated in the regulation of the expression of the above genes during SMC proliferation.

\section{CONCLUSION}

In this study, LPS was found to have a profound effect on SMC gene expression profile and the induction of many genes involved in cellular transcription, translation, signal transduction and metabolism indicates the activated state of SMC. This global change in genetic profile may be the main force 
that drives the LPS-induced phenotypic transition of SMC rather than the differential expression of a single gene or a few genes. The induction of genes involved in cell proliferation, adhesion, motility and matrix formation suggests that LPS mediated SMC transition from the quiescent to proliferative, synthetic and migratory phenotype. Many genes associated with apoptosis, both pro- and anti-, were also differentially regulated by LPS suggesting that the balance in cell survival and death was somehow tilted although the direction is not clear. Since LPS is the ligand for TLR4 that is a part of host innate immune system, genes involved in host defense are activated expectedly. The LPS response is not due solely to primary TLR4 signaling pathway but also the combinatory effect of various signaling pathways activated by the interaction of several ligands with their cognate receptors that are induced in this system. This will consist of LPS interacting with TLR4 in the presence of CD14 and LBP as well as the interaction of growth factors, interleukins, interferons and TGFb with their receptors.

\section{ACKNOWEDGMENTS}

This work was supported by grants from the University of Toronto, Faculty of Medicine, Dean's Research Fund (to J.M) and Genome Canada (to S.D).

\section{REFERENCES}

1. Ross, R., 1999. Atherosclerosis--an inflammatory disease. N. Engl. J. Med., 340 (2): 115-126.

2. Lusis, A.J., 2000. Atherosclerosis. Nature, 407 (6801): 233-241.

3. Gaydos, C.A., J.T. Summersgill, N.N. Sahney, J.A. Ramirez and T.C. Quinn, 1996. Replication of Chlamydia pneumoniae in vitro in human macrophages, endothelial cells and aortic artery smooth muscle cells. Infect. Immun., 64 (5): 1614-1620.

4. Shor, A. and J.I. Phillips, 1999. Chlamydia pneumoniae and atherosclerosis. Jama, 282 (21): 2071-2073.

5. Detmer, K., Z. Wang, D. Warejcka, S.K. LeeperWoodford and W.H. Newman, 2001. Endotoxin stimulated cytokine production in rat vascular smooth muscle cells. Am. J. Physiol. Heart Circ. Physiol., 281 (2): H661-668.

6. Kaukoranta-Tolvanen, S.S., A.M. Teppo, K. Laitinen, P. Saikku, K. Linnavuori and M. Leinonen, 1996. Growth of Chlamydia pneumoniae in cultured human peripheral blood mononuclear cells and induction of a cytokine response. Microb. Pathog., 21 (3): 215-221.
7. Kalayoglu, M.V. and G.I. Byrne, 1998. A Chlamydia pneumoniae component that induces macrophage foam cell formation is chlamydial lipopolysaccharide. Infect. Immun., 66 (11): 5067-5072.

8. Liao, W., 1996. Endotoxin: Possible roles in initiation and development of atherosclerosis. J. Lab. Clin. Med., 128 (5): 452-460.

9. Libby, P., P.M. Ridker and A. Maseri, 2002. Inflammation and atherosclerosis. Circulation, 105 (9): 1135-1143.

10. Rice, J.B., L.L. Stoll, W.G. Li, G.M. Denning, J. Weydert, E. Charipar, W.E. Richenbacher, F.J. Miller, Jr. and N.L. Weintraub, 2003. Lowlevel endotoxin induces potent inflammatory activation of human blood vessels: inhibition by statins. Arterioscler. Thromb. Vasc. Biol., 23 (9): 1576-1582.

11. Danenberg, H.D., F.G. Welt, M. Walker, P. Seifert, G.S. Toegel and E.R. Edelman, 2002. Systemic inflammation induced by lipopolysaccharide increases neointimal formation after balloon and stent injury in rabbits. Circulation, 105 (24): 2917-2922.

12. Seydel, U., A.B. Schromm, R. Blunck and K. Brandenburg, 2000. Chemical structure, molecular conformation and bioactivity of endotoxins. Chem. Immunol., 74: 5-24.

13. Hailman, E., H.S. Lichenstein, M.M. Wurfel, D.S. Miller, D.A. Johnson, M. Kelley, L.A. Busse, M.M. Zukowski and S.D. Wright, 1994. Lipopolysaccharide (LPS)-binding protein accelerates the binding of LPS to CD14. J. Exp. Med., 179 (1): 269-277.

14. Simmons, D.L., S. Tan, D.G. Tenen, A. NicholsonWeller and B. Seed, 1989. Monocyte antigen CD14 is a phospholipid anchored membrane protein. Blood, 73 (1): 284-289.

15. Wright, S.D., R.A. Ramos, P.S. Tobias, R.J. Ulevitch and J.C. Mathison, 1990. CD14, a receptor for complexes of lipopolysaccharide (LPS) and LPS binding protein. Science, 249 (4975): 1431-1433.

16. Lin, F.Y., Y.H. Chen, Y.W. Lin, J.S. Tsai, J.W. Chen, H.J. Wang, Y.L. Chen, C.Y. Li and S.J. Lin, 2006. The role of human antigen R, an RNA-binding protein, in mediating the stabilization of toll-like receptor $4 \mathrm{mRNA}$ induced by endotoxin: a novel mechanism involved in vascular inflammation. Arterioscler. Thromb. Vasc. Biol., 26 (12): 2622-2629. 
17. Lin, F.Y., Y.H. Chen, J.S. Tasi, J.W. Chen, T.L. Yang, H.J. Wang, C.Y. Li, Y.L. Chen and S.J. Lin, 2006. Endotoxin induces toll-like receptor 4 expression in vascular smooth muscle cells via NADPH oxidase activation and mitogen-activated protein kinase signaling pathways. Arterioscler. Thromb. Vasc. Biol., 26 (12): 2630-2637.

18. Sasu, S., D. LaVerda, N. Qureshi, D.T. Golenbock and D. Beasley, 2001. Chlamydia pneumoniae and chlamydial heat shock protein 60 stimulate proliferation of human vascular smooth muscle cells via toll-like receptor 4 and p44/p42 mitogen-activated protein kinase activation. Circ. Res., 89 (3): 244-250.

19. Schletter, J., H. Brade, L. Brade, C. Kruger, H. Loppnow, S. Kusumoto, E.T. Rietschel, H.D. Flad and A.J. Ulmer, 1995. Binding of lipopolysaccharide (LPS) to an 80-kilodalton membrane protein of human cells is mediated by soluble CD14 and LPS-binding protein. Infect. Immun., 63 (7): 2576-2580.

20. Stoll, L.L., G.M. Denning, W.G. Li, J.B. Rice, A.L. Harrelson, S.A. Romig, S.T. Gunnlaugsson, F.J. Miller, Jr. and N.L. Weintraub, 2004. Regulation of endotoxin-induced proinflammatory activation in human coronary artery cells: expression of functional membrane-bound CD14 by human coronary artery smooth muscle cells. J. Immunol., 173 (2): 1336-1343.

21. Zhang, G. and S. Ghosh, 2000. Molecular mechanisms of NF-kappaB activation induced by bacterial lipopolysaccharide through Toll-like receptors. J. Endotoxin Res., 6 (6): 453-457.

22. Engelmann, M.G., C.V. Redl and S. Nikol, 2004. Recurrent perivascular inflammation induced by lipopolysaccharide (endotoxin) results in the formation of atheromatous lesions in vivo. Lab. Invest., 84 (4): 425-432.

23. Engelmann, M.G., C.V. Redl, J. Pelisek, C. Barz, J. Heesemann and S. Nikol, 2006. Chronic perivascular inoculation with Chlamydophila pneumoniae results in plaque formation in vivo. Lab. Invest., 86 (5): 467-476.

24. Eisen, M.B., P.T. Spellman, P.O. Brown and D. Botstein, 1998. Cluster analysis and display of genome-wide expression patterns. Proc. Natl. Acad. Sci. U.S.A., 95 (25): 14863-14868.

25. Yun, J.J., L.E. Heisler, Hwang, II, O. Wilkins, S.K. Lau, M. Hyrcza, B. Jayabalasingham, J. Jin, J. McLaurin, M.S. Tsao and S.D. Der, 2006. Genomic DNA functions as a universal external standard in quantitative real-time PCR. Nucleic Acids Res., 34 (12): e85.
26. Loppnow, H., F. Stelter, U. Schonbeck, C. Schluter, M. Ernst, C. Schutt and H.D. Flad, 1995. Endotoxin activates human vascular smooth muscle cells despite lack of expression of CD14 mRNA or endogenous membrane CD14. Infect. Immun., 63 (3): 1020-1026.

27. Barbosa de Oliveira, L.C., C.J. Rocha Oliveira, D.M. Fries, A. Stern and H.P. Monteiro, 2002. Effects of lipopolysaccharide on low- and highdensity cultured rabbit vascular smooth muscle cells: differential modulation of nitric oxide release, ERK1/ERK2 MAP kinase activity, protein tyrosine phosphatase activity and DNA synthesis. Braz. J. Med. Biol. Res., 35 (2): 181-190.

28. Lin, F.Y., Y.H. Chen, Y.L. Chen, T.C. Wu, C.Y. Li, J.W. Chen and S.J. Lin, 2007. Ginkgo biloba Extract Inhibits Endotoxin-Induced Human Aortic Smooth Muscle Cell Proliferation via Suppression of Toll-like Receptor 4 Expression and NADPH Oxidase Activation. J. Agric. Food Chem., 55 (5): 1977-1984.

29. Golech, S.A., R.M. McCarron, Y. Chen, J. Bembry, F. Lenz, R. Mechoulam, E. Shohami and M. Spatz, 2004. Human brain endothelium: coexpression and function of vanilloid and endocannabinoid receptors. Brain Res. Mol. Brain Res., 132 (1): 87-92.

30. Kobayashi, D., S. Koshida, R. Moriai, N. Tsuji and N. Watanabe, 2007. Olfactomedin 4 promotes S-phase transition in proliferation of pancreatic cancer cells. Cancer Sci., 98 (3): 334-340.

31. Chabicovsky, M., K. Herkner and W. Rossmanith, 2003. Overexpression of activin beta(C) or activin beta(E) in the mouse liver inhibits regenerative deoxyribonucleic acid synthesis of hepatic cells. Endocrinology, 144 (8): 3497-3504.

32. Nicholl, M.J., L.H. Robinson and C.M. Preston, 2000. Activation of cellular interferon-responsive genes after infection of human cells with herpes simplex virus type 1.J. Gen. Virol., 81 (Pt 9): 2215-2218.

33. Ye, S., H. Pang, Y.Y. Gu, J. Hua, X.G. Chen, C.D. Bao, Y. Wang, W. Zhang, J. Qian, B.P. Tsao, B.H. Hahn, S.L. Chen, Z.H. Rao and N. Shen, 2003. Protein interaction for an interferoninducible systemic lupus associated gene, IFIT1. Rheumatology (Oxford), 42 (10): 1155-1163.

34. Hui, D.J., C.R. Bhasker, W.C. Merrick and G.C. Sen, 2003. Viral stress-inducible protein p56 inhibits translation by blocking the interaction of eIF3 with the ternary complex eIF2.GTP.MettRNAi. J. Biol. Chem., 278 (41): 39477-39482. 
35. Bluyssen, H.A., R.J. Vlietstra, P.W. Faber, E.M. Smit, A. Hagemeijer and J. Trapman, 1994. Structure, chromosome localization and regulation of expression of the interferon-regulated mouse Ifi54/Ifi56 gene family. Genomics, 24 (1): 137-148.

36. Schwer, H., L.Q. Liu, L. Zhou, M.T. Little, Z. Pan, C.J. Hetherington and D.E. Zhang, 2000. Cloning and characterization of a novel human ubiquitinspecific protease, a homologue of murine UBP43 (Usp18). Genomics, 65 (1): 44-52.

37. Li, N., W. Zhang and X. Cao, 2000. Identification of human homologue of mouse IFN-gamma induced protein from human dendritic cells. Immunol. Lett., 74 (3): 221-224.

38. Csiszar, K., 2001. Lysyl oxidases: a novel multifunctional amine oxidase family. Prog. Nucleic Acid Res. Mol. Biol., 70: 1-32.

39. Peinado, H., M. Del Carmen Iglesias-de la Cruz, D. Olmeda, K. Csiszar, K.S. Fong, S. Vega, M.A. Nieto, A. Cano and F. Portillo, 2005. A molecular role for lysyl oxidase-like 2 enzyme in snail regulation and tumor progression. Embo J., 24 (19): 3446-3458.

40. Didierlaurent, A., B. Brissoni, D. Velin, N. Aebi, A. Tardivel, E. Kaslin, J.C. Sirard, G. Angelov, J. Tschopp and K. Burns, 2006. Tollip regulates proinflammatory responses to interleukin-1 and lipopolysaccharide. Mol. Cell. Biol., 26 (3): 735-742.

41. Thomas, M.C. and C.M. Chiang, 2006. The general transcription machinery and general cofactors. Crit. Rev. Biochem. Mol. Biol., 41 (3): 105-178.

42. Martic, G., Z. Karetsou, K. Kefala, A.S. Politou, C.R. Clapier, T. Straub and T. Papamarcaki, 2005. Parathymosin affects the binding of linker histone $\mathrm{H} 1$ to nucleosomes and remodels chromatin structure. J. Biol. Chem., 280 (16): 16143-16150.

43. Nakamura, F., R.G. Kalb and S.M. Strittmatter, 2000. Molecular basis of semaphorin-mediated axon guidance. J. Neurobiol., 44 (2): 219-229.

44. Tamagnone, L., S. Artigiani, H. Chen, Z. He, G.I. Ming, H. Song, A. Chedotal, M.L. Winberg, C.S. Goodman, M. Poo, M. Tessier-Lavigne and P.M. Comoglio, 1999. Plexins are a large family of receptors for transmembrane, secreted and GPIanchored semaphorins in vertebrates. Cell, 99 (1): 71-80.

45. Gambaro, K., E. Aberdam, T. Virolle, D. Aberdam and M. Rouleau, 2006. BMP-4 induces a Smaddependent apoptotic cell death of mouse embryonic stem cell-derived neural precursors. Cell Death Differ., 13 (7): 1075-1087.
46. Varga, A.C. and J.L. Wrana, 2005. The disparate role of BMP in stem cell biology. Oncogene, 24 (37): 5713-5721.

47. Yu, P.B., H. Beppu, N. Kawai, E. Li and K.D. Bloch, 2005. Bone morphogenetic protein (BMP) type II receptor deletion reveals BMP ligand-specific gain of signaling in pulmonary artery smooth muscle cells. J. Biol. Chem., 280 (26): 24443-24450.

48. Cloutier, A., T. Ear, E. Blais-Charron, C.M. Dubois and P.P. McDonald, 2007. Differential involvement of NF-\{kappa $\} \mathrm{B}$ and MAP kinase pathways in the generation of inflammatory cytokines by human neutrophils. J. Leukoc. Biol., 81 (2): 567-577.

49. Pennica, D., T.A. Swanson, J.W. Welsh, M.A. Roy, D.A. Lawrence, J. Lee, J. Brush, L.A. Taneyhill, B. Deuel, M. Lew, C. Watanabe, R.L. Cohen, M.F. Melhem, G.G. Finley, P. Quirke, A.D. Goddard, K.J. Hillan, A.L. Gurney, D. Botstein and A.J. Levine, 1998. WISP genes are members of the connective tissue growth factor family that are upregulated in wnt-1-transformed cells and aberrantly expressed in human colon tumors. Proc. Natl. Acad. Sci. U.S.A., 95 (25): 14717-14722.

50. Suwa, A., M. Mitsushima, T. Ito, M. Akamatsu, K. Ueda, T. Amachi and N. Kioka, 2002. Vinexin beta regulates the anchorage dependence of ERK2 activation stimulated by epidermal growth factor. J. Biol. Chem., 277 (15): 13053-13058.

51. Xu, L., R.B. Corcoran, J.W. Welsh, D. Pennica and A.J. Levine, 2000. WISP-1 is a Wnt-1- and betacatenin-responsive oncogene. Genes Dev., 14 (5): 585-595.

52. Libby, P., J.M. Ordovas, L.K. Birinyi, K.R. Auger and C.A. Dinarello, 1986. Inducible interleukin-1 gene expression in human vascular smooth muscle cells. J. Clin. Invest., 78 (6): 1432-1438.

53. Aarden, L., M. Helle, L. Boeije, D. PascualSalcedo and E. de Groot, 1991. Differential induction of interleukin-6 production in monocytes, endothelial cells and smooth muscle cells. Eur. Cytokine Netw., 2 (2): 115-120.

54. Van Dervort, A.L., L. Yan, P.J. Madara, J.P. Cobb, R.A. Wesley, C.C. Corriveau, M.M. Tropea and R.L. Danner, 1994. Nitric oxide regulates endotoxin-induced TNF-alpha production by human neutrophils. J. Immunol., 152 (8): 4102-4109.

55. Lo, Y.C., C.C. Wang, K.P. Shen, B.N. Wu, K.L. Yu and I.J. Chen, 2004. Urgosedin inhibits hypotension, hypoglycemia and pro-inflammatory mediators induced by lipopolysaccharide. J. Cardiovasc. Pharmacol., 44 (3): 363-371. 
56. Ikeda, U., K. Okada, S. Ishikawa, T. Saito, T. Kasahara and K. Shimada, 1995. Monocyte chemoattractant protein 1 inhibits growth of rat vascular smooth muscle cells. Am. J. Physiol., 268 (3 Pt 2): H1021-1026.

57. Wang, X., T.L. Yue, E.H. Ohlstein, C.P. Sung and G.Z. Feuerstein, 1996. Interferon-inducible protein10 involves vascular smooth muscle cell migration, proliferation and inflammatory response. J. Biol. Chem., 271 (39): 24286-24293.

58. Yoshimura, T., M. Takeya, H. Ogata, S. Yamashiro, W.S. Modi and R. Gillitzer, 1999. Molecular cloning of the guinea pig GRO gene and its rapid expression in the tissues of lipopolysaccharide-injected guinea pigs. Int. Arch. Allergy Immunol., 119 (2): 101-111.

59. Nakano, T., O. Ohara, H. Teraoka and H. Arita, 1990. Group II phospholipase A2 mRNA synthesis is stimulated by two distinct mechanisms in rat vascular smooth muscle cells. FEBS Lett., 261 (1): 171-174.

60. Ermert, L., M. Ermert, M. Merkle, M. GoppeltStruebe, H.R. Duncker, F. Grimminger and W. Seeger, 2000. Rat pulmonary cyclooxygenase-2 expression in response to endotoxin challenge: Differential regulation in the various types of cells in the lung. Am. J. Pathol., 156 (4): 1275-1287.

61. Li, H., M.I. Cybulsky, M.A. Gimbrone, Jr. and P. Libby, 1993. Inducible expression of vascular cell adhesion molecule-1 by vascular smooth muscle cells in vitro and within rabbit atheroma. Am. J. Pathol., 143 (6): 1551-1559.

62. Chen, X.L., P.E. Tummala, L. Olliff and R.M. Medford, 1997. E-selectin gene expression in vascular smooth muscle cells. Evidence for a tissue-specific repressor protein. Circ. Res., 80 (3): 305-311.

63. Beck-Schimmer, B., R.C. Schimmer, R.L. Warner, H. Schmal, G. Nordblom, C.M. Flory, M.E. Lesch, H.P. Friedl, D.J. Schrier and P.A. Ward, 1997. Expression of lung vascular and airway ICAM-1 after exposure to bacterial lipopolysaccharide. Am. J. Respir. Cell Mol. Biol., 17 (3): 344-352.

64. Wong, H.R., B.R. Pitt, G.L. Su, D.P. Rossignol, A.R. Steve, T.R. Billiar and S.C. Wang, 1995. Induction of lipopolysaccharide-binding protein gene expression in cultured rat pulmonary artery smooth muscle cells by interleukin 1 beta. Am. J. Respir. Cell Mol. Biol., 12 (4): 449-454.

65. Choi, H.C. and K.Y. Lee, 2004. CD14 glycoprotein expressed in vascular smooth muscle cells. J. Pharmacol. Sci., 95 (1): 65-70.
66. Shoji, H., N. Minamino, K. Kangawa and H. Matsuo, 1995. Endotoxin markedly elevates plasma concentration and gene transcription of adrenomedullin in rat. Biochem. Biophys. Res. Commun., 215 (2): 531-537.

67. Yet, S.F., A. Pellacani, C. Patterson, L. Tan, S.C. Folta, L. Foster, W.S. Lee, C.M. Hsieh and M.A. Perrella, 1997. Induction of heme oxygenase1 expression in vascular smooth muscle cells. A link to endotoxic shock. J. Biol. Chem., 272 (7): 4295-4301.

68. Nagase, M., J. Abe, K. Takahashi, J. Ando, S. Hirose and T. Fujita, 1998. Genomic organization and regulation of expression of the lectin-like oxidized low-density lipoprotein receptor (LOX-1) gene. J. Biol. Chem., 273 (50): 33702-33707.

69. Li, W., T. Tada, T. Miwa, N. Okada, J. Ito, H. Okada, H. Tateyama and T. Eimoto, 1999. mRNA expression of complement components and regulators in rat arterial smooth muscle cells. Microbiol. Immunol., 43 (6): 585-593.

70. Matsumura, M., H. Kakishita, M. Suzuki, N. Banba and Y. Hattori, 2001. Dexamethasone suppresses iNOS gene expression by inhibiting NF-kappaB in vascular smooth muscle cells. Life Sci., 69 (9): 1067-1077.

71. Wei, C.Y., K.C. Huang, Y.H. Chou, P.F. Hsieh, K.H. Lin and W.W. Lin, 2006. The role of Rhoassociated kinase in differential regulation by statins of interleukin-1beta- and lipopolysaccharide-mediated nuclear factor kappaB activation and inducible nitric-oxide synthase gene expression in vascular smooth muscle cells. Mol. Pharmacol., 69 (3): 960-967.

72. Bucher, M. and K. Taeger, 2002. Endothelinreceptor gene-expression in rat endotoxemia. Intensive Care Med., 28 (5): 642-647.

73. Olofsson, P.S., K. Jatta, D. Wagsater, S. Gredmark, U. Hedin, G. Paulsson-Berne, C. SoderbergNaucler, G.K. Hansson and A. Sirsjo, 2005. The antiviral cytomegalovirus inducible gene 5/viperin is expressed in atherosclerosis and regulated by proinflammatory agents. Arterioscler. Thromb. Vasc. Biol., 25 (7): e113-116.

74. Wu, S.Q. and W.C. Aird, 2005. Thrombin, TNFalpha and LPS exert overlapping but nonidentical effects on gene expression in endothelial cells and vascular smooth muscle cells. Am. J. Physiol. Heart Circ. Physiol., 289 (2): H873-885. 
75. Ohashi, N., A. Matsumori, Y. Furukawa, K. Ono, M. Okada, A. Iwasaki, T. Miyamoto, A. Nakano and S. Sasayama, 2000. Role of p38 mitogenactivated protein kinase in neointimal hyperplasia after vascular injury. Arterioscler. Thromb. Vasc. Biol., 20 (12): 2521-2526.

76. Glover, J.N. and S.C. Harrison, 1995. Crystal structure of the heterodimeric bZIP transcription factor c-Fos-c-Jun bound to DNA. Nature, 373 (6511): 257-261.

77. Takaoka, A., S. Hayakawa, H. Yanai, D. Stoiber, H. Negishi, H. Kikuchi, S. Sasaki, K. Imai, T. Shibue, K. Honda and T. Taniguchi, 2003. Integration of interferon-alpha/beta signalling to p53 responses in tumour suppression and antiviral defence. Nature, 424 (6948): 516-523.
78. Rinaldo, C., A. Prodosmo, F. Mancini, S. Iacovelli, A. Sacchi, F. Moretti and S. Soddu, 2007. MDM2regulated degradation of HIPK2 prevents p53Ser46 phosphorylation and DNA damage-induced apoptosis. Mol. Cell, 25 (5): 739-750.

79. Vogelstein, B. and K.W. Kinzler, 1992. p53 function and dysfunction. Cell, 70 (4): 523-526. 